\title{
Enterprise Interoperability Assessment: A Requirements Engineering
} Approach

\author{
Gabriel S. S. Leal ${ }^{\mathrm{a}, \mathrm{b}}$, Wided Guédria ${ }^{\mathrm{a}, \mathrm{b}^{*}}$, Hervé Panetto ${ }^{\mathrm{b}}$ \\ ${ }^{a}$ Luxembourg Institute of Science and Technology, Esch-sur-Alzette, Luxembourg \\ \{gabriel.leal; wided.guedria\}@list.lu \\ b Université de Lorraine, CNRS, CRAN, Nancy, France ; (herve.panetto@univ- \\ lorraine.fr) \\ * Corresponding author: Dr. Wided Guédria \\ Postal Address: LIST, 5, Avenue des Hauts-Fourneaux, L-4362 Esch-sur-Alzette, \\ Luxembourg \\ Email : wided.guedria@list.lu
}

One of the main challenges within collaborative business ecosystems is the management of Interoperability. Indeed, Interoperability is a crucial prerequisite that must be satisfied when enterprises need to work together for seizing new business opportunities and improving competitiveness. To develop and improve enterprise systems interoperability, a set of interoperability requirements needs to be verified. Indeed, knowing the different requirements and their relationships are paramount for identifying potential impacts on the overall system. Many research work have been proposed in the literature for defining and analysing such requirements. However, existing work do not explicitly specify the interdependencies between interoperability requirements. The objective of this article is, therefore, to investigate and define the interoperability requirements and their interdependencies. This will provide a holistic and clear view of the relations between the system components and their associated requirements. Therefore, one will be able to identify potential causes of the non-fulfilment of requirements, and their impacts on the concerned system. To do so, a Requirements Engineering approach is used to identify and formalise interoperability requirements and their relationships.

Keywords: collaborative ecosystem; enterprise interoperability; interoperability assessment; interoperability requirement; requirements engineering; system alignment 


\section{Introduction}

Enterprises face many challenges leading them to self-adapt to remain competitive in the current fast-changing environment (Op't Land et al., 2009). For instance, many companies, despite their sector of activity, are shifting boundaries and participating in collaborative networks with the objective to provide highly personalised and integrated products while seamlessly reducing cost and time (Camarinha-Matos and Afsarmanesh, 2005), (European Commission, 2016). Another recent phenomenon is the increase in the number of enterprises and costumers participating in the collaborative economy through collaborative platforms. Indeed, such platforms enable individuals and other actors such as micro-entrepreneurs and businesses to offer their services to a larger number of interested customers (European Commission, 2016).

In this collaborative context, Interoperability is a prerequisite that must be satisfied for ensuring collaboration (Chen et al., 2007), (Panetto, 2007), (JardimGoncalves et al., 2012). Predominantly, it refers to the ability of systems to exchange information and use the information that has been exchanged (IEEE, 1991). When this ability is not achieved, it becomes a problem that should be solved (Naudet et al., 2010). Indeed, interoperability problems can influence the performance and the outcomes of enterprises and networks drastically. For instance, the U.S. Department of Commerce Technology Administration estimates a cost of U\$15.8 billion related to the inadequate interoperability between systems in the U.S. Capital Facilities Industry (Gallaher et al., 2004). The West Health Institute estimates a potential of U\$ 30 billion addressable waste per year related to the lack of interoperability across segments of health care in the U.S. (West Health Institute, 2013).

When enterprises encounter interoperability related problems, they should plan coherent transformations of their enterprise systems, to improve interoperability and 
solve the identified problems, while working seamlessly. In other words, enterprises should be aware of their strengths and weaknesses in terms of interoperability, to plan corrective actions when needed. Assessing the enterprise systems is frequently the initial step toward a new collaboration development or an improvement program.

An assessment is a systematic, independent and documented process for obtaining evidence regarding the defined evaluation criteria and evaluating it objectively against a standard or set of guidelines to determine the quality of the assessed system (ISO 9000, 2015), (ISO/IEC 33001, 2015). Therefore, the Interoperability Assessment (INAS) has the objective to analyse the interoperability, before, during or after any collaboration between enterprise systems for identifying interoperability problems and associated solutions (Ford et al., 2007a), (Guédria et al., 2015), (Panetto et al., 2016). When assessing systems regarding their interoperability, a certain number of Interoperability Requirements (IR) should be verified (Chen et al., 2007), (Daclin et al., 2016), (Leal et al., 2017). These requirements define the needs of stakeholders regarding interoperability. In certain cases, for improving the system interoperability based on the assessment outcomes, changes may be necessary within the concerned system (Guédria et al., 2015), (Agostinho et al., 2016). For example, when there is a need for including or excluding particular enterprise systems function and for adding or eliminating processes connections among companies. However, such changes at the enterprise systems level embody an immediate evolution and present a disturbance to the networked enterprise (Agostinho et al., 2016). Hence, the alignment between enterprises systems and their related requirements should also be taken into account when assessing and improving systems interoperability (Goepp and Avila, 2015), (Leal et al., 2017).

However, based on a systematic literature review (Leal et al., 2019a), the authors observed that few INAS approaches are considering IR related to different 
interoperability barriers and their interdependencies. The authors argue that the use of multiple approaches to cover a holistic view of enterprise interoperability might cause: a) redundancy and confusion when more than one INAS approach is considered for the same barrier; and b) difficulties on relating evaluation results as in general the approaches use different metrics and rating scales. In addition, no INAS approach explicitly addresses the interdependences between their requirements, which hinder the identification of impacts caused by non-fulfilled requirements on the overall system.

Considering the presented context, the objective of this paper is to investigate and define the relationships between IR of a given system. The authors argue that the defined requirements interdependencies support the identification of potential problems and impact on the assessed system. To define the requirements interdependencies, the adopted Requirements Engineering' approach follows the international standard ISO 29148 (ISO/IEC 29148, 2011), (Loucopoulos and Karakostas, 1995). Among the reviewed INAS approaches, the Maturity Model for Enterprise Interoperability (MMEI) (Guédria et al., 2015), (ISO 11354-2, 2015) is adopted as a reference assessment model. This choice is done given the fact that the MMEI is the only maturity model that, following a systemic approach, provides a holistic view considering the different interoperability barriers (Guédria et al., 2015), (Leal et al., 2019a). Further, to identify and define the requirements interdependencies, the adopted Requirements Engineering' approach follows the international standard ISO 29148 (ISO/IEC 29148, 2011).

The remainder of the paper is structured as follows: the Research Methodology describes the followed research steps. A review of the related work is presented in the section State-of-the-art. It is followed by the Solution proposal. The Design and Development section elaborates on the IR elicitation and the interdependencies between them. In the Evaluation section, the proposed contribution is validated through a case 
study based on a real business scenario. Finally, the Conclusion section concludes the paper and some future work are brought forward.

\section{Research methodology}

The research methodology adopted in this work follows the guidelines of the Design

Science Research Methodology proposed by (Peffers et al., 2007). The methodology is following an iterative process as depicted in Figure 1.

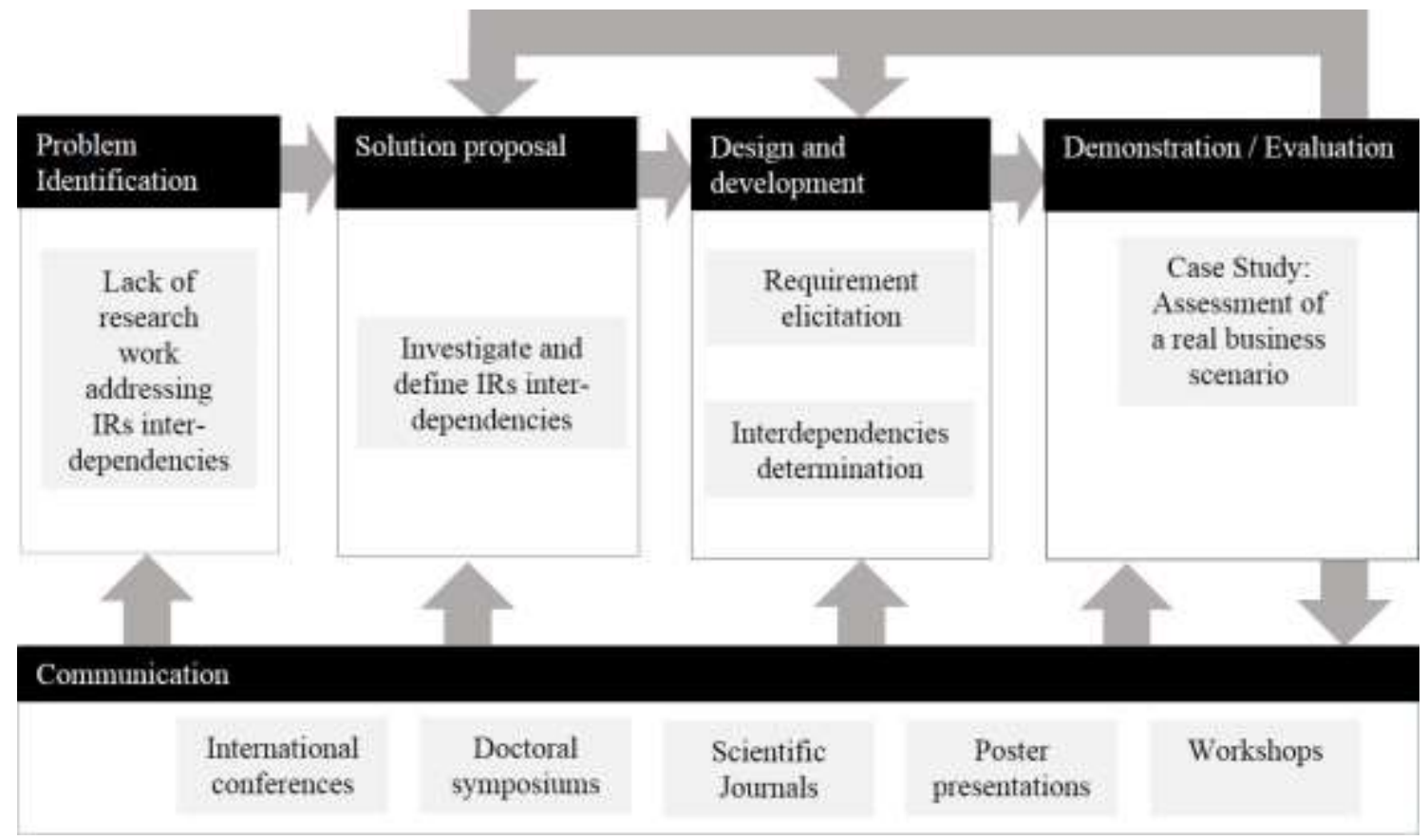

Figure 1. The research methodology. Adapted from (Peffers et al., 2007)

The methodology is divided into six steps: (1) identify problem based on a literature review; (2) define solution objectives considering the limitation found during the literature review; (3) design and development of the contribution, i.e. the interoperability requirements elicitation and interdependencies determination; (4) demonstration based on a real case study; (5) evaluation based on the results from the conducted study; and (6) communication. 


\section{State-of-the-art}

In this section, the fundamentals of the Enterprise Interoperability domain are reviewed through the most relevant Interoperability frameworks. Relevant related work regarding the definition of interoperability requirements are also presented. Further, the current INAS approaches and their proposed evaluation criteria are reviewed. Finally, the Requirements Engineering domain is brought forward by studying its life cycle as well as techniques for elicitation, decomposing and formalising requirements.

\subsection{Enterprise Interoperability}

In this research work, an "Enterprise" is seen as "one or more organisations sharing a definite mission, goals and objectives to offer an output such as a product or a service" (ISO 15704, 2000). Given this definition, we assume that the term "enterprise" encompasses all types of organizations: companies, government, non-profit, supply chains, virtual enterprises, as well as parts of a company such as a division or program.

Further, it is important to note that the concept of interoperability is different from the concept of collaboration. Generally speaking, interoperability is the ability or the aptitude of two systems that have to understand one another and to function together (Chen et al., 2007). In the enterprise context, "Enterprise Interoperability" provides two, or more, business entities the ability to exchange or share information and of using the functionality of one another in a distributed and heterogeneous environment (Chen et al., 2007), (Panetto et al., 2016). The next subsections explore interoperability frameworks, requirements and assessment approaches.

\subsubsection{Framework for Enterprise Interoperability}

In the past years, many researchers have proposed frameworks to describe the 
Interoperability domain. The most well-known frameworks are: the European Interoperability Framework (EIF) (EIF, 2017), proposed by the European Commission, focusing on providing knowledge for interoperability between public administration services. EIF is a European standard, which is more and more adopted by public administration around Europe (Gatti et al., 2016); the ATHENA Interoperability Framework (AIF) (Berre et al., 2007) focusing on enterprise application interoperability and providing a reference architecture for capturing the research elements and solutions to interoperability issues; and the Framework for Enterprise Interoperability (FEI) (Chen et al., 2007) describing different barriers to interoperability and potential approaches to be adopted for solving the identified barriers. It also important to note that FEI had become an international standard under the number ISO 11354-1 (ISO 11354-1, 2011).

New interoperability frameworks have been also proposed in recent years. However, they are domain specific such as the Internet of Things based interoperability framework (Backman et al., 2016) for fleet management, the Smart City Interoperability Framework (Ahn et al., 2016), the interoperability framework for software as service systems in cloud (Rezaei et al., 2014a), the International Image Interoperability Framework (Snydman et al., 2015) and the conceptual interoperability framework for large-scale systems (Selway et al., 2017).

For the purpose of our research, the FEI is considered as it is a generic framework (i.e. can be used by enterprises from different sectors of activity) and it covers multiple dimensions of interoperability.

The aim of FEI is to structure the concepts of enterprise interoperability domain. The framework has three basic dimensions: Interoperability Concerns, which represent the different levels of an enterprise where interoperation can take place; Interoperability Barriers, which refer to the incompatibilities between two enterprise systems; and 
Interoperability Approaches regarding the solutions to be implemented for removing identified barriers. The intersection between the Interoperability Barriers and Concerns results in twelve sub-domains, which represents the interoperability problem space.

Table 1 presents some examples of enterprise elements where interoperability barriers may appear when at least two companies interact. The interested reader can find more examples of barriers in (Chen et al., 2007) and (Ullberg et al., 2009).

Table 1. Examples of enterprise elements related to interoperability barriers. Adapted from (Chen et al., 2007)

\begin{tabular}{|c|c|c|c|}
\hline & Conceptual & Technical & Organisational \\
\hline Business & $\begin{array}{l}\text { visions, strategies, cultures, } \\
\text { understanding }\end{array}$ & IT infrastructure & $\begin{array}{l}\text { methods of works, legislations, } \\
\text { organisation structures }\end{array}$ \\
\hline Process & $\begin{array}{l}\text { syntax and semantics of } \\
\text { processes }\end{array}$ & $\begin{array}{l}\text { process enactment } \\
\text { of engine }\end{array}$ & $\begin{array}{l}\text { procedures of work, operation } \\
\text { modes, processes organisation }\end{array}$ \\
\hline Service & $\begin{array}{l}\text { semantics to name and describe } \\
\text { services }\end{array}$ & $\begin{array}{l}\text { interface, } \\
\text { architecture }\end{array}$ & $\begin{array}{l}\text { responsibility /authority to manage } \\
\text { services }\end{array}$ \\
\hline Data & $\begin{array}{l}\text { data representation and } \\
\text { semantics, data restriction rule }\end{array}$ & $\begin{array}{l}\text { data exchange } \\
\text { formats }\end{array}$ & $\begin{array}{l}\text { responsibility/ authority to } \\
\text { add/delete, change/ update data }\end{array}$ \\
\hline
\end{tabular}

In this research work, the twelve sub-domains defined based on the cross sections between Interoperability Barriers and Concerns are considered for organising the interoperability requirements.

\subsubsection{Interoperability Requirements}

In order to achieve a higher quality of interoperability between enterprises, a certain number of Interoperability Requirements (IR) should be satisfied. Such requirements are statements defining what should be in place for ensuring an effective interoperation, and consequently collaboration between two or more enterprise systems (Chen et al., 2007), (Mallek et al., 2012). 
Based on a literature review, 291 papers that have been proposed to study IRs from different domains were identified, from 1981 to early 2018. Among them, only 8 papers explicitly defining and presenting interoperability requirements. For instance, the paper (Jochem and Knothe, 2007) proposes a Quality Model for Interoperability (QMI) containing sets of IRs according to the type of collaboration (i.e. Virtual Enterprise, Supply Chain, Joint Venture, and Strategic Alliance). The authors in (Alemany et al., 2010) define 26 IRs regarding a collaborative planning process based on FEI. The authors in (Neiva et al., 2016) propose a model for supporting pragmatic interoperability in software projects. The model contains 9 IRs for ensuring interoperability between software systems and 12 IRs for ensuring interoperability between organisations.

Based on a literature review and an industrial survey, (Mallek et al., 2012) formulate 86 IRs in a collaborative process between two enterprises. The proposed requirements are classified into four categories (compatibility, interoperation, autonomy and reversibility) and organised based on the Interoperability Barriers and Concerns proposed by FEI. In (Chituc et al., 2009) 12 IRs are defined for a collaborativecompetitive economic networked environment. Based on the IRs, the authors propose a collaborative interoperability framework for identifying the main actors and their activities regarding interoperability. Finally, the authors in (Cornu et al., 2012) define 80 IRs for technical processes deployment in large companies.

\subsubsection{Interoperability Assessment Approaches}

Enterprises should benefit from the use of INAS to verify IRs compliance and to determine their systems strengths and weaknesses regarding interoperations. It involves identifying the needs, or gaps, between where companies envision themselves in the future and the company's current states. 
Based on the surveys and reviews such as (Ford et al., 2007b), (Guédria et al., 2008), (Rezaei et al., 2014b), (Leal et al., 2019a), the majority of the INAS are explicitly providing a set of evaluation criteria.

For example, the Interoperability Maturity Assessment of Public Services (IMAPS) model (European Commission, 2018) proposed by the European Commission provides a set of evaluation criteria related to the legal, technical, organisational and semantic layers of interoperability. The Health Information Systems Interoperability Maturity Toolkit (MEASURE Evaluation Team, 2017) defines 40 evaluation criteria related to different components of a health information system. Based on the fulfilment of the defined criteria, the interoperability maturity of the health information systems is determined.

The Public Administration Interoperability Capability Model (PAICM) (Cestari et al., 2019) proposes 22 attributes for evaluating interoperability among public administrations. PAICM also considers all barriers and concerns proposed in the FEI (Chen et al., 2007). Finally, the MMEI (Guédria et al., 2015) defines 48 evaluation criteria for assessing the interoperability potential of an enterprise. Each criterion is related to a barrier and concerned as defined in FEI.

\subsection{Requirements Engineering}

Requirements Engineering (RE) can be defined as the systematic process of developing requirements through an iterative combining process of examining the problem, documenting the resulting observations, and verifying the accuracy of the obtained knowledge (Loucopoulos and Karakostas, 1995), (Salinas et al., 2008). Indeed, the set of requirements obtained through a RE approach enables an agreed understanding between stakeholders and provides a basis for verifying designs and accepting system solutions (ISO/IEC 29148, 2011). 
Many frameworks have been proposed in the literature to describe the general processes of a RE. For instance, the authors in (Loucopoulos and Karakostas, 1995) proposes a framework containing three RE processes focusing on the development of software systems: (1) the first process refers to the elicitation of the requirements based on the stakeholders' needs and on the knowledge extracted from the concerned domain. (2) The second process produces a formal requirements models, which have two main objectives: to serve as an agreement between stakeholders and developers, and to serve as a blueprint for the development of the system. (3) The third and last process refers to the validation of requirements. The aim of such process is to certify that the requirements model is consistent with stakeholders' intentions and needs.

The international standard ISO 29148 (ISO/IEC 29148, 2011) describes three processes. The Stakeholder Requirements Definition process that have the objective to to determine the system requirements that can provide the functions needed by users and other stakeholders in a defined environment. The purpose of the Requirements Analysis process is to transform the stakeholder, requirement-driven view of desired functions into a technical view of a required system that could deliver those functions. These first two processes result in a set of requirements, which flow into the Architectural Design process where the requirements are allocated, decomposed and traced to system elements. In some instances, additional requirement statements should be created to define relationships between the architectural elements of the system, to provide necessary clarity in the context of the lower levels of abstraction of the system elements (ISO/IEC 29148, 2011).

Relevant techniques for supporting the overall RE process have been also identified, such as the requirements elicitation (Loucopoulos and Karakostas, 1995), requirements formalisation (Eriksson et al., 2009), (Peres et al., 2012) and system 
requirements modelling (Panetto et al., 2004), (Amyot et al., 2010), (ISO/IEC 29148, 2011), (OMG, 2017a).

\section{Solution proposal: An approach for defining interoperability requirements interdependencies}

Based on the research context and the literature review, few INAS approaches are considering interoperability requirements related to different interoperability barriers and concerns at the same time. In addition, no INAS approach explicitly addresses the interdependences between requirements. For these reasons, the aim of this paper is to address the following research problem: The lack of INAS approaches explicitly addressing the interdependences between their considered interoperability requirements.

Considering the identified research problem, the authors propose to investigate and define the interoperability requirements interdependencies, to ensure a global view of the current state of the assessed systems. In order to address the hereinabove objective, an RE approach for the definition of the IRs interdependencies based on the work of (Loucopoulos and Karakostas, 1995) and (ISO/IEC 29148, 2011) is proposed. The four steps of the defined approach are described hereinafter.

1) Requirement Elicitation: The requirements can be extracted from the IR related literature and from INAS approaches. However, none of the reviewed work is explicitly defining the interdependencies of their IRs or evaluation criteria. Nonetheless, the MMEI (Guédria et al., 2015) was adopted as the reference assessment model for this research work. The reasons for choosing this approach are: (1) it defines twelve interoperability areas which contain evaluation criteria that should be satisfied to avoid barriers related to an enterprise level; (2) It adopts a systemic approach allowing to instantiate 
different types of enterprises; (3) It recently became an international standard under the number ISO 11354-2:2015 (ISO 11354-2, 2015).

2) Requirement Decomposition and Formalisation: The decomposition and formalisation are done in order to formalise requirements. Indeed, such step supports the identification of similarities and dependencies between requirements. The formalisation can reduce requirements ambiguity and support the automation of the requirement analysis, when developing automated approach. Therefore, in this step, the formal framework for the formalization of informal requirements defined in (Peres et al., 2012) is adopted. One of the main advantages of this framework is that it provides an iterative process supported by a formal structure: The Pseudo-Requirement Graph, which consists in two types of nodes (refinements and pseudorequirements).

3) Requirement Architectural Design: According to (ISO/IEC 29148, 2011), it is crucial to define requirement statements at more detailed levels of abstraction than just the overall system. This is accomplished by allocating the system requirements to the system elements. Regarding the modelling language, the System Modelling Language (SysML) (OMG, 2017a) is adopted as it is a well-known standard and can be used to model any kind of system e.g. enterprises, networked enterprises, software applications, etc.

4) Requirement Interdependencies Identification: The requirements interdependencies are based on the requirements and enterprises elements relationships.

As illustrated in Figure 2, the first step is the extraction of the evaluation criteria from MMEI. Next, the extracted criteria is formalised using the iterative methodology 
proposed in (Peres et al., 2012). Further, the formalised requirements are related with the concerned enterprise elements. Finally, the interdependencies are inferred based on the determined relationships.

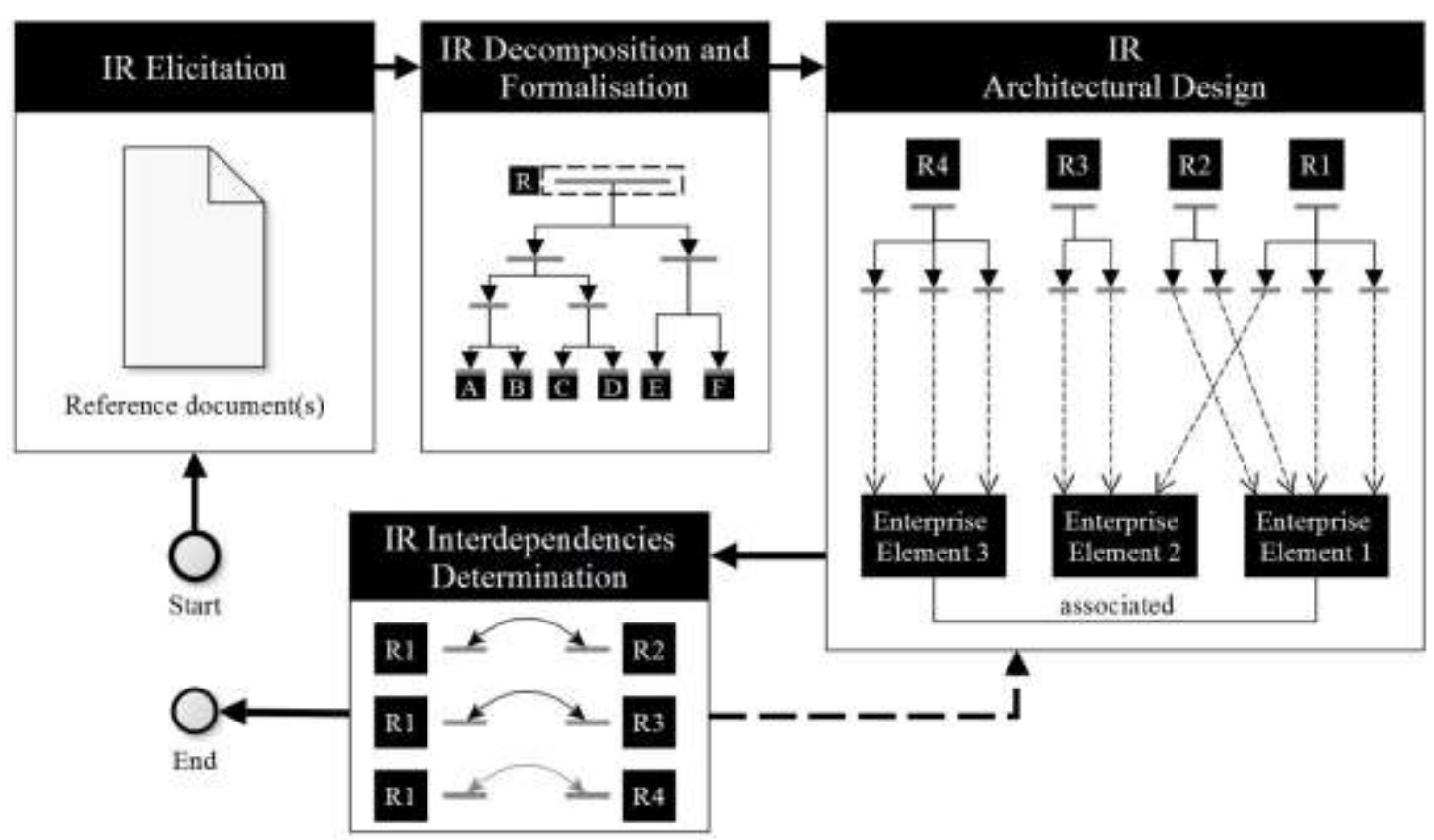

Figure 2. The approach for defining IRs interdependencies

Comparing to the existing INAS approaches cited in section in section 3.1.3 and reviewed in (Ford et al., 2007b), (Guédria et al., 2008), (Rezaei et al., 2014b), (Leal et al., 2019a), the novelty of our approach consists in the formalization and the visualization of interoperability requirements interdependencies. Indeed, acknowledging the different dependencies among and between them supports the identification of impacts on the overall system.

\section{Design and Development: Determining the Interoperability Requirements interdependencies}

This section covers the application of the proposed RE approach for defining interoperability requirement interdependencies. 


\subsection{Interoperability Requirements Elicitation}

The first step of our RE approach is the interoperability requirement elicitation. As mentioned before, the forty-eight interoperability evaluation criteria defined on the MMEI (Guédria et al., 2015) are adopted as interoperability requirements.

The (ISO/IEC 29148, 2011) recommendations were followed for writing the interoperability requirements based on the evaluation criteria. It means that, the criteria proposed on MMEI were re-written for clearly expressing requirements.

According to the (ISO/IEC 29148, 2011), requirements should state what is needed for the concerned system and not include design decisions for it. Regarding the requirement construct, superlative, subjective language, comparative phrases and ambiguous adverbs should be avoided. As requirements are binding provisions, the use of the term 'shall' when describing the actions of the concerned subject (i.e. system) is mandatory.

Table 2 to Table 5 show the requirements. They are organised according to the interoperability areas defined in MMEI. Each area represents the cross-section between an Interoperability Barrier (Conceptual, Technological and Organisational) and an Interoperability Concern (Business, Process, Service and Data).

To facilitate the identification, an ID was attributed to each requirement, which it is composed of the first letter of the related Interoperability Concern, the first letter of the related Interoperability Barrier. These are followed by the letter " $R$ ", meaning that it is a requirement. The related maturity level follows it. For example, the ID "BCR1" represents the requirement related to the Business concern and the Conceptual barrier from the maturity level 1. 
Table 2. Interoperability Requirements relate to the Business concern. Adapted from (Guédria et al., 2015)

\begin{tabular}{|c|c|c|c|c|c|}
\hline ID & Conceptual & ID & Technological & ID & Organisational \\
\hline BCR1 & $\begin{array}{l}\text { Business models shall be } \\
\text { defined and documented }\end{array}$ & BTR1 & $\begin{array}{l}\text { Basic IT infrastructure } \\
\text { shall be in place }\end{array}$ & BOR1 & $\begin{array}{l}\text { Organization structure shall be } \\
\text { defined and in place and legal } \\
\text { aspects shall be defined }\end{array}$ \\
\hline BCR2 & $\begin{array}{l}\text { Standards shall be used for } \\
\text { alignment with other } \\
\text { business models }\end{array}$ & BTR2 & $\begin{array}{l}\text { Standard } \\
\text { configurable } \\
\text { infrastructures shall be } \\
\text { used }\end{array}$ & BOR2 & $\begin{array}{l}\text { Human resources shall be trained } \\
\text { for interoperability }\end{array}$ \\
\hline BCR3 & $\begin{array}{l}\begin{array}{l}\text { Business models shall be } \\
\text { designed for }\end{array} \text { multi } \\
\text { partnership } \\
\text { collaborative enterprise }\end{array}$ & BTR3 & $\begin{array}{l}\text { IT infrastructure shall } \\
\text { be open }\end{array}$ & BOR3 & $\begin{array}{l}\text { Organization structure shall be } \\
\text { flexible }\end{array}$ \\
\hline BCR4 & $\begin{array}{l}\text { Business model shall be } \\
\text { adaptive }\end{array}$ & BTR4 & $\begin{array}{l}\text { IT infrastructure shall } \\
\text { be adaptive }\end{array}$ & BOR4 & $\begin{array}{l}\text { Organization shall be agile for on- } \\
\text { demand business }\end{array}$ \\
\hline
\end{tabular}

Table 3. Interoperability Requirements relate to the Process concern. Adapted from

(Guédria et al., 2015)

\begin{tabular}{|c|c|c|c|c|c|}
\hline ID & Conceptual & ID & Technological & ID & Organisational \\
\hline PCR1 & $\begin{array}{l}\text { Process models shall } \\
\text { be defined and } \\
\text { documented }\end{array}$ & PTR1 & $\begin{array}{l}\text { IT support shall support processes } \\
\text { and ad hoc exchange of process } \\
\text { information shall be possible }\end{array}$ & POR1 & $\begin{array}{l}\text { Processes responsibilities } \\
\text { and authorities shall be } \\
\text { defined and put in place }\end{array}$ \\
\hline PCR2 & $\begin{array}{l}\text { Standards shall be } \\
\text { used for alignment } \\
\text { with other process } \\
\text { models }\end{array}$ & PTR2 & $\begin{array}{l}\text { Standard process tools and platforms } \\
\text { shall be available }\end{array}$ & POR2 & $\begin{array}{l}\text { Procedures for processes } \\
\text { interoperability shall be in } \\
\text { place }\end{array}$ \\
\hline PCR3 & $\begin{array}{l}\text { Meta-modelling shall } \\
\text { be done for multiple } \\
\text { process model } \\
\text { mappings }\end{array}$ & PTR3 & $\begin{array}{l}\text { Platform(s) and tool(s) for } \\
\text { collaborative execution of processes } \\
\text { shall be available }\end{array}$ & POR3 & $\begin{array}{l}\text { Cross-enterprise } \\
\text { collaborative processes } \\
\text { management shall be in } \\
\text { place }\end{array}$ \\
\hline PCR4 & \begin{tabular}{ll} 
Process & \multicolumn{2}{l}{ modelling } \\
shall be done for \\
dynamic & re- \\
engineering &
\end{tabular} & PTR4 & $\begin{array}{l}\text { Dynamic and adaptive tool(s) and } \\
\text { engines for processes shall be } \\
\text { available }\end{array}$ & POR4 & $\begin{array}{l}\text { Real-time monitoring of } \\
\text { processes, } \\
\text { procedures shall be in place }\end{array}$ \\
\hline
\end{tabular}

Table 4. Interoperability Requirements relate to the Service concern. Adapted from

(Guédria et al., 2015)

\begin{tabular}{|c|c|c|c|c|c|}
\hline ID & Conceptual & ID & Technological & ID & Organisational \\
\hline SCR1 & $\begin{array}{l}\text { Service models shall be } \\
\text { defined and documented }\end{array}$ & STR1 & $\begin{array}{l}\text { Applications/services shall be } \\
\text { connectable and ad hoc } \\
\text { information exchange shall be } \\
\text { possible }\end{array}$ & SOR1 & $\begin{array}{l}\text { Service responsibilities } \\
\text { and authorities shall be } \\
\text { defined and put in place }\end{array}$ \\
\hline SCR2 & $\begin{array}{l}\text { Standards shall be used for } \\
\text { alignment with other } \\
\text { service models }\end{array}$ & STR2 & $\begin{array}{l}\text { Standardise and configurable } \\
\text { service architecture(s) and } \\
\text { interface(s) shall be available }\end{array}$ & SOR2 & $\begin{array}{l}\text { Procedures for services } \\
\text { interoperability shall be in } \\
\text { place }\end{array}$ \\
\hline SCR3 & $\begin{array}{l}\text { Meta-modelling shall be } \\
\text { done for multiple service } \\
\text { model mappings }\end{array}$ & STR3 & $\begin{array}{l}\text { Automated services discovery and } \\
\text { composition shall be possible and } \\
\text { shared applications shall be in } \\
\text { place }\end{array}$ & SOR3 & $\begin{array}{l}\text { Collaborative services and } \\
\text { application management } \\
\text { shall be in place }\end{array}$ \\
\hline SCR4 & $\begin{array}{l}\text { Service modelling shall be } \\
\text { adaptive }\end{array}$ & STR4 & $\begin{array}{l}\text { Dynamically composable services } \\
\text { and networked applications shall } \\
\text { be in place }\end{array}$ & SOR4 & $\begin{array}{l}\text { Dynamic service and } \\
\text { application management } \\
\text { rules and methods shall be } \\
\text { in place }\end{array}$ \\
\hline
\end{tabular}


Table 5. Interoperability Requirements relate to the Data concern. Adapted from (Guédria et al., 2015)

\begin{tabular}{|c|c|c|c|c|c|}
\hline ID & Conceptual & ID & Technological & ID & Organisational \\
\hline DCR1 & $\begin{array}{l}\text { Data models shall be } \\
\text { defined and documented }\end{array}$ & DTR1 & $\begin{array}{l}\text { Data storage devices shall be } \\
\text { connectable and simple } \\
\text { electronic exchange shall be } \\
\text { possible }\end{array}$ & DOR1 & $\begin{array}{l}\text { Responsibilities and } \\
\text { authorities shall be } \\
\text { defined and in place }\end{array}$ \\
\hline DCR2 & $\begin{array}{l}\text { Standards shall be used } \\
\text { for alignment with other } \\
\text { data models }\end{array}$ & DTR2 & $\begin{array}{l}\text { Automated access to data based } \\
\text { on standard protocols shall be in } \\
\text { place }\end{array}$ & DOR2 & $\begin{array}{l}\text { Rules and methods for } \\
\text { data management shall } \\
\text { be in place }\end{array}$ \\
\hline DCR3 & $\begin{array}{l}\text { Meta-modelling shall be } \\
\text { done for multiple data } \\
\text { model mappings }\end{array}$ & DTR3 & $\begin{array}{l}\text { Remote access to databases shall } \\
\text { be possible for applications and } \\
\text { shared data shall be available }\end{array}$ & DOR3 & $\begin{array}{lr}\text { Personalized } & \text { data } \\
\text { management } & \text { for } \\
\text { different partners } & \text { shall } \\
\text { be in place } & \\
\end{array}$ \\
\hline DCR4 & $\begin{array}{l}\text { Data models shall be } \\
\text { adaptive (considering } \\
\text { both syntax and } \\
\text { semantics) }\end{array}$ & DTR4 & $\begin{array}{l}\text { Direct database } \\
\text { capability and full data } \\
\text { conversion tool(s) shall be in } \\
\text { place }\end{array}$ & DOR4 & $\begin{array}{l}\text { Adaptive } \text { data } \\
\text { management rules and } \\
\text { methods shall be in } \\
\text { place }\end{array}$ \\
\hline
\end{tabular}

The authors argue that this set of IR can be used in different sectors of activity since the "enterprise" is considered in a systemic view. Indeed, as pointed out in section 3.1, the term "enterprise" encompasses: companies, public administration, military organisations, manufactures, etc.

For example, let's take the requirement "PCR1 - Process models shall be defined and documented".

- When considering a public administration, the process may refer to the delivery of the passport to a citizen. For grating the passport to a citizen, interoperations may happen between different public systems (Public finance, police, etc.) according to the concerned Country.

- When considering a manufacturing company such as an automobile manufacturer, the process may refer to assembly line. For instance, for assembly the car parts before painting it, a set of interoperation may be performed by different systems (e.g. robots, sensors, entire operator teams).

Despite the sector of activity, the process(es) that may be involved in interoperations should be defined and documented. 


\subsection{Interoperability Requirements Decomposition and Formalisation}

In the following subsections, the methodology for requirement decomposition and formalisation proposed by (Peres et al., 2012) is described. Next, as an example, the formalisation of the requirements from the Process Interoperability Concern regarding the maturity level 1 is presented.

\subsubsection{The decomposition and formalisation process}

To address the IRs decomposition and formalisation, the formal framework for requirement formalisation proposed in (Peres et al., 2012) is adopted, as it provides an iterative methodology for decomposing and formalising informal requirements (i.e. natural language written requirements). This methodology follows a top-down approach starting from requirements directly taken from the requirements document and ends with the formalised requirements. The methodology is illustrated in Figure 3 and described hereinafter. 


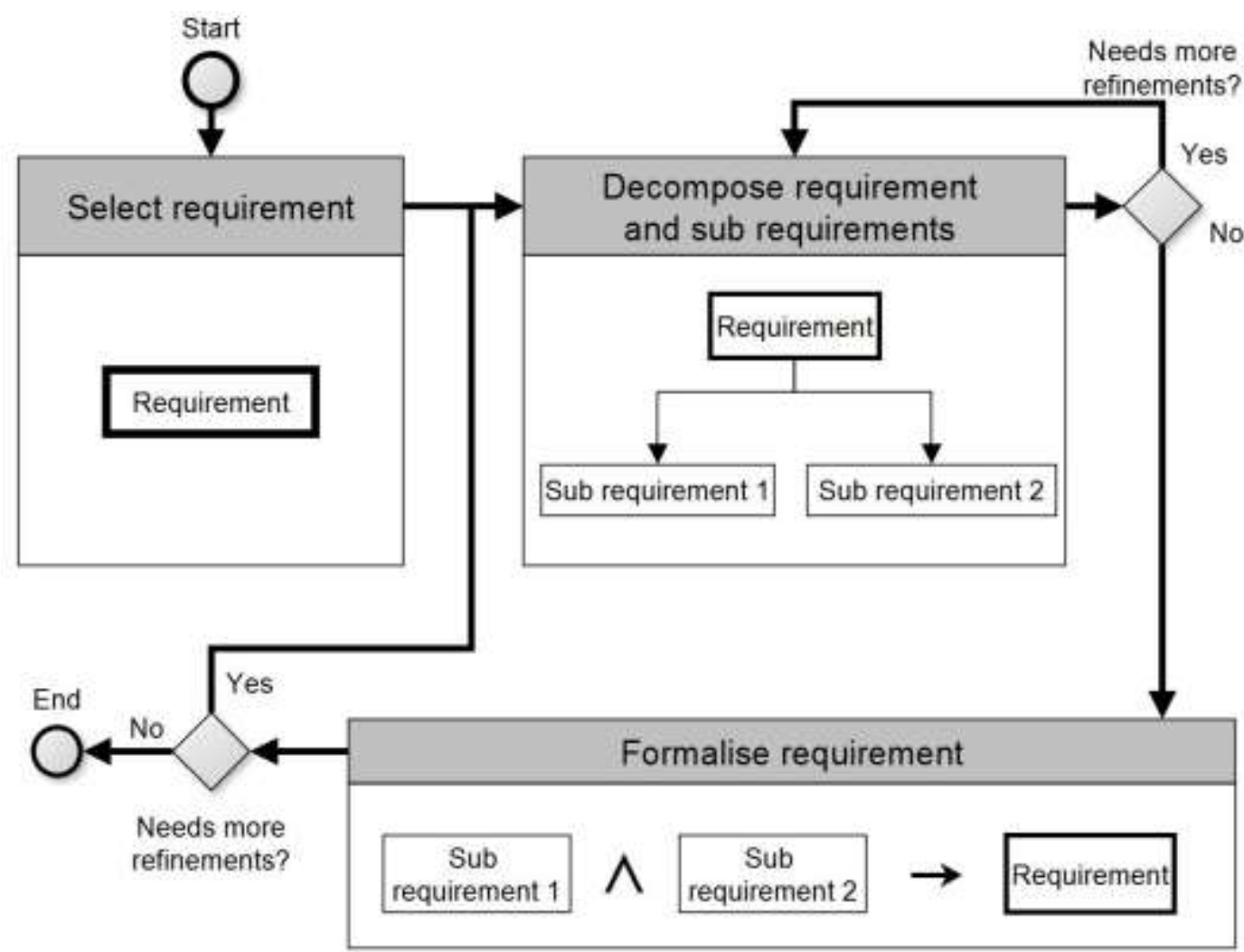

Figure 3. The three main steps of the decomposition and formalisation methodology.

Adapted from (Peres et al., 2012)

The first step consists on selecting a requirement from the considered document of reference. Therefore, for each requirement, the three steps of this methodology are applied. The second step is the decomposition of the selected requirement. It is supported by a formal graph structure called the Pseudo-Requirement Graph. Such graph has three main elements:

- Pseudo-requirement, which is a requirement, a sub requirement, or an atomic requirement.

- Atomic requirements are equivalent to the atomic statements defined in logic, which is a statement that cannot be broken down into smaller statements.

- Refinements, which are the paths from the high-level requirement until the atomics requirements. The type of refinement must be chosen and specified. Four 
categories are adopted, which are: (a) Precision: when a pseudo-requirement must be disambiguated; (b) Abstraction: when a pseudo-requirement is described in too much details regarding the system which is being studied; (c) Correction: when the pseudo-requirement is incorrect; (d) Decomposition: when the pseudorequirement can be decomposed in several pseudo-requirement.

In the case of a refinement, its category should be chosen and applied. The outcome is one or multiple pseudo-requirements, which are linked with the refined requirement. The refinements are done until all the atomic requirements are defined and no other modification is needed. The authors argue that the atomic requirements are defined based on the desired granularity level, the awareness of the environment in which the requirement is applied and the related context (e.g. interoperability).

Further, four elements are related to the refinement: What (identifies the concerned pseudo-requirement), Why (explains why the refinement is helpful), How (describes the result of modifying what is pointed out by the What according to what is explained by the Why), and finally, the Link (describes how the refined pseudorequirement is related to the pseudo-requirement(s) resulting from the refinement). Figure 4 illustrates an example of a requirement decomposition using the Pseudo-Requirement Graph.

In Figure 4, the dashed rectangle represents the requirement extracted directly from the document of reference. The rounded rectangles represent the types of refinement. It includes an explanation why the refinement is helpful, how the refinement is done and what are the links of the resulting refinement. The ordinary rectangles represent the pseudo requirements resulting from the refinements. The rectangles with thick lines represent the atomic requirements. 


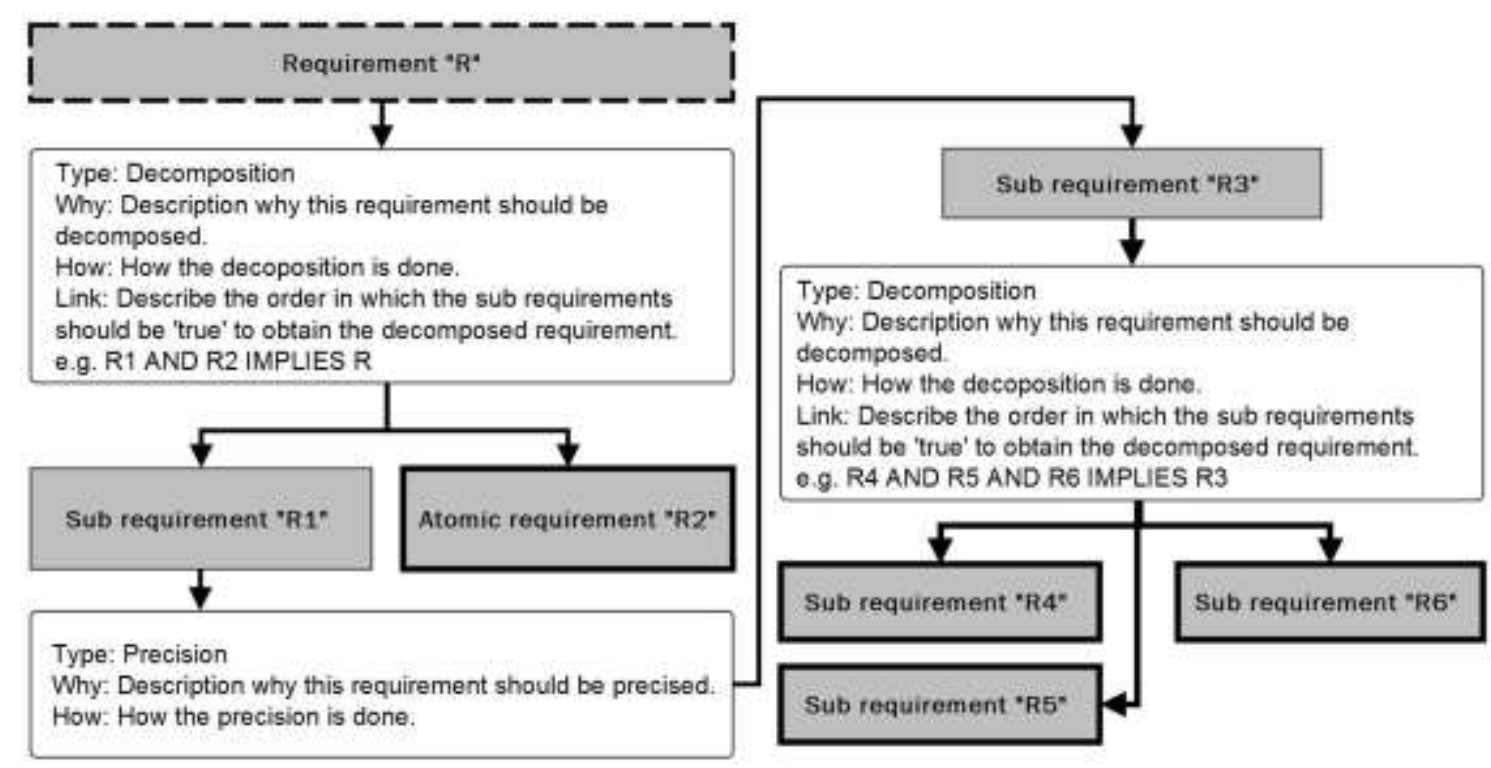

Figure 4. Example of a requirement decomposition using the Pseudo-Requirement Graph

Finally, the third step refers to the formalisation of the decomposed requirement, based on the identified Links. The formal language used is the same as defined in (Peres et al., 2012). It is a combination of the usual logical connectors from the first-order logic (Nienhuys-Cheng and Wolf, 1997), and the $U$ temporal connector from the CTL* (Computer Tree Logic) (Emerson and Halpern, 1986).

The $U$ temporal connector is useful for formalising temporal conditions. This connector means "hold until" and implies the notion of temporal dependency between two variables. For example, let us take the requirement "BCRl: Business models shall be defined and documented" and two of its sub requirements "BCR1.1: Business models shall be defined" and "BCR1.2: Business models shall be documented".

In general, it is not possible to document a business model (BCR1.2) before it is defined (BCR1.1). Therefore, it is paramount to include the notion of time for formalising this kind of situation. Indeed, $B C R 1.2$ can be only considered true when $B C R 1.1$ is already true and is sustained as true. In other words, the statement $B C R 1.1 \cup B C R 1.2 \rightarrow B C R 1$ means that $B C R 1.1$ holds until BCR1.2 happens. 


\subsubsection{The decomposition and formalisation of the IR from the Process Interoperability Concern}

For demonstrating the decomposition and formalisation of the interoperability requirements, the described methodology is applied on three requirements from the Process Interoperability Concern regarding the maturity level 1 . These requirements are "PCR1: Process models shall be defined and documented"; "POR1: Process responsibilities and authorities shall be defined and in place"; and "PTR1: IT support for processes shall be in place and Ad hoc exchange of information shall be possible".

Figure 5 illustrates the decomposition of the requirement PCR1 using the PseudoRequirement Graph. Table 6 shows the decomposition and formalisation of this same requirement.

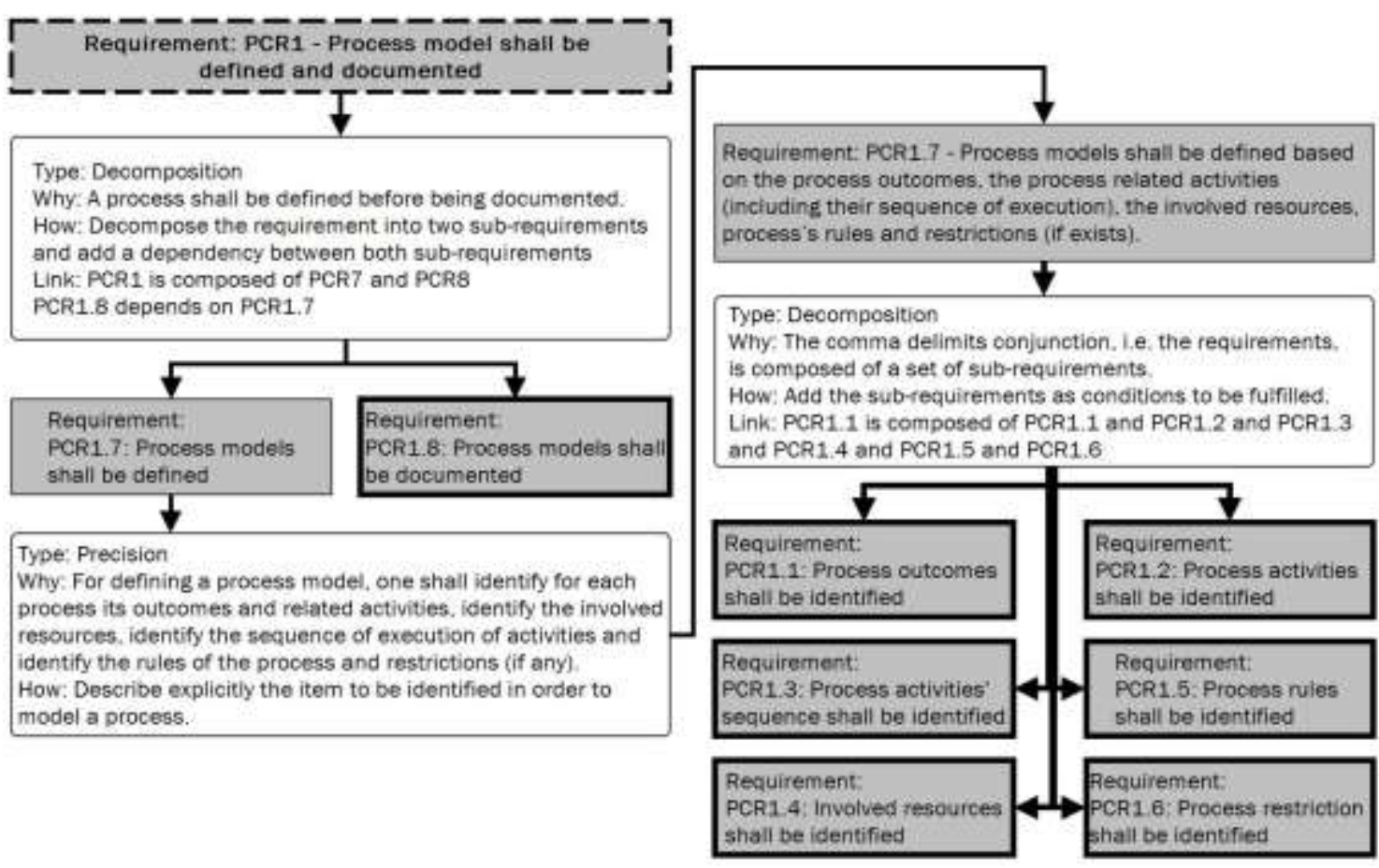

Figure 5. Decomposition of the requirement PCR1 
Table 6. Requirement PCR1

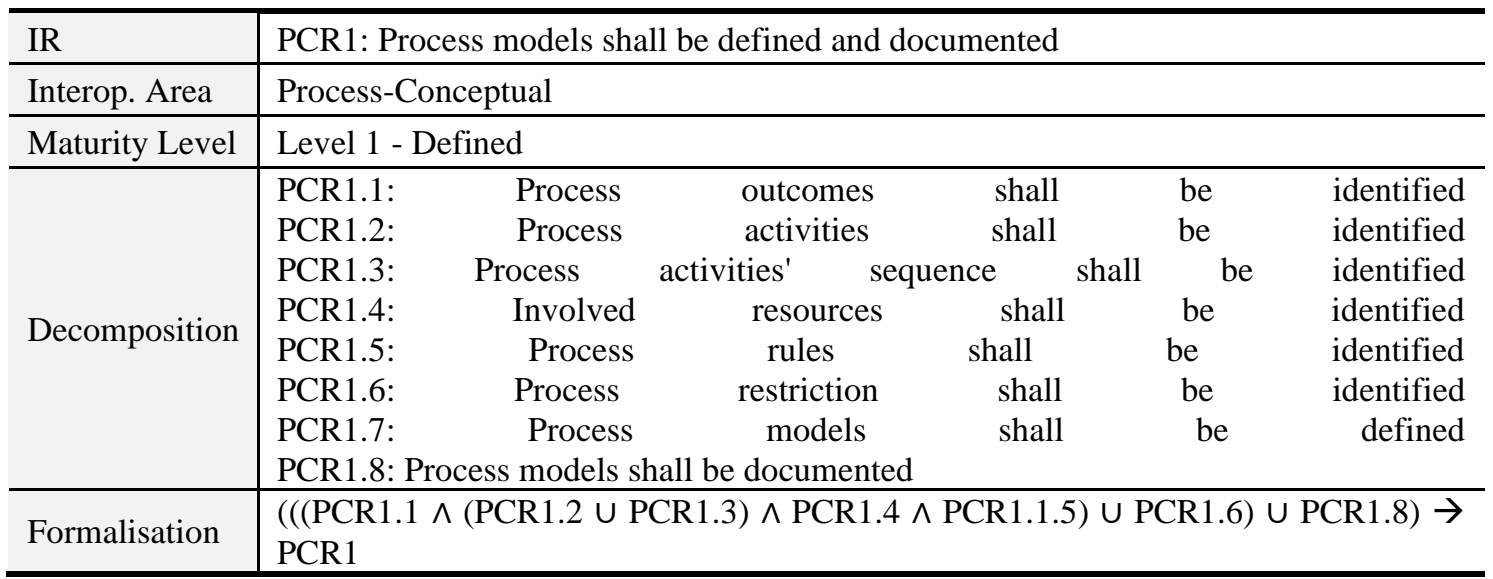

\subsection{Interoperability Requirements Architectural Design}

To identify and represent interdependencies between requirements from the interoperability areas, it is important to establish a sound and common understanding of the requirements relations to enterprise elements (e.g. process models, information systems, etc.).

To do so, a conceptual model is designed as illustrated in Figure 6 using the SysML notation (OMG, 2017a). The "Enterprise" class can be instantiated to any kind of business organisation, hospitals, public administration, etc. The "Enterprise Element" is a class that can be generalised to any type of element that is relevant to the enterprise e.g. an Actor, a Software application, a Process, a Document, etc. These generalisations are distinguished by two related powertypes: tangible and intangible elements. The "Requirement" is a class that can be instantiate to any Interoperability Requirement. To represent the relationships between requirement and a design element (e.g. enterprise system), the "satisfy" relationship is used to describe how a design or implementation model satisfies one or more requirements. 

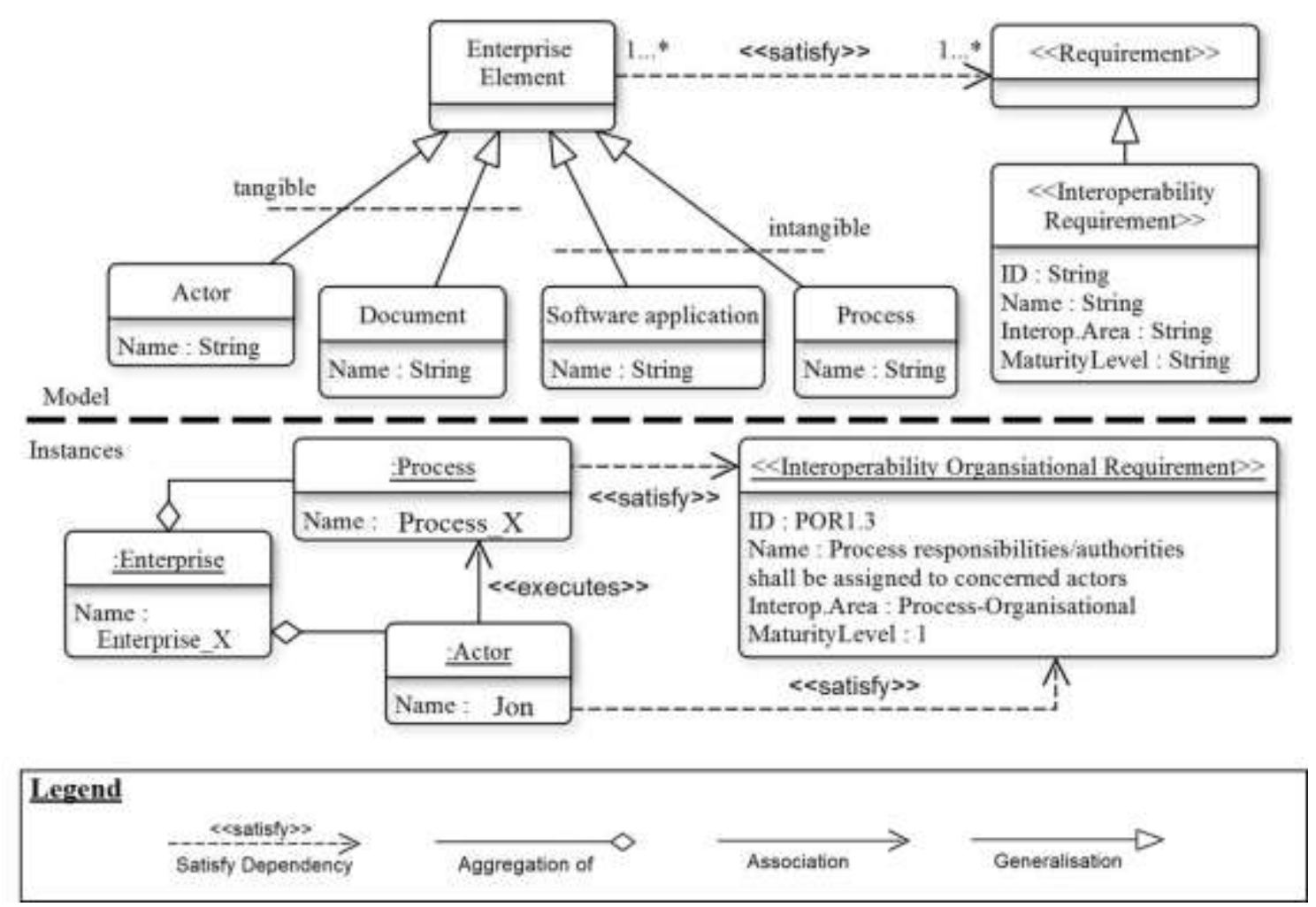

Figure 6. Modelling IRs and enterprise elements relations

Figure 6 also illustrates an instantiation example, considering the Interoperability Requirement "POR1.3", and the Enterprise Elements "Jon" as an Actor and "Process_X" as a Process.

In the following, the relationships between the IRs from the Business-Conceptual interoperability area to relevant enterprise elements are presented.

Four IRs are associated to the Business-Conceptual interoperability area as shown in the Table 7. 
Table 7. The IRs from the Business-Conceptual interoperability area

\begin{tabular}{|c|c|}
\hline पент & Decomposition \\
\hline $\begin{array}{l}\text { BCR1: Business } \\
\text { models shall be defined } \\
\text { and documented }\end{array}$ & 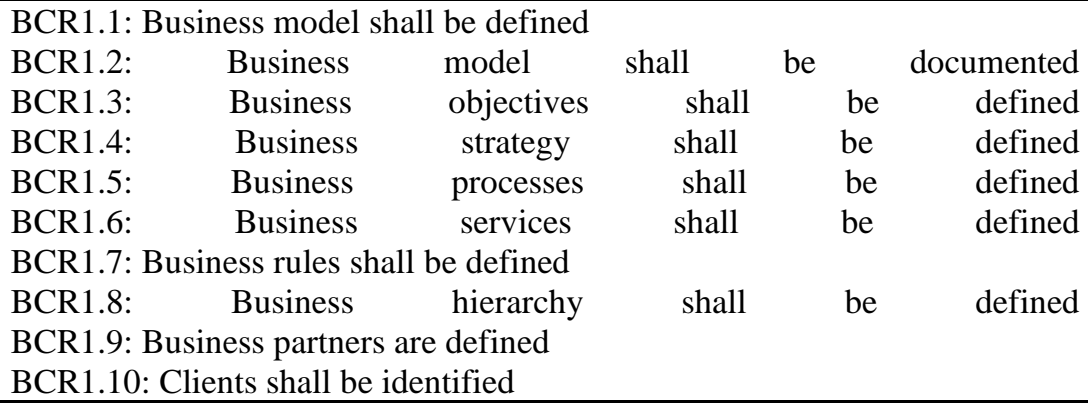 \\
\hline $\begin{array}{l}\text { BCR2: Standards shall } \\
\text { be used for alignment } \\
\text { with other business } \\
\text { models }\end{array}$ & $\begin{array}{l}\text { BCR2.1: Standards used in the enterprise environment shall be iden } \\
\text { BCR2.2: Standards shall be selected and used for modelling business }\end{array}$ \\
\hline $\begin{array}{lr}\text { BCR3: } & \text { Business } \\
\text { Models shall be } \\
\text { designed } \\
\text { collaboration }\end{array}$ & $\begin{array}{l}\text { BCR3.1 Core business subject to potential collaboration shall be identified } \\
\text { BCR3.2: Preferred partners shall be identified } \\
\text { BCR3.3: Potential collaborations shall be included in the defined business } \\
\text { model } \\
\text { BCR3.4: The documented business model shall be updated }\end{array}$ \\
\hline $\begin{array}{l}\text { BCR4: } \\
\text { models } \\
\text { adaptive }\end{array}$ & $\begin{array}{l}\text { BCR4.1: Periodic review procedure shall be defined to adapt business model } \\
\text { BCR4.2: Periodic review procedure shall be implemented to adapt business } \\
\text { model } \\
\text { BCR4.3: A reuse-centric strategy shall be adopted } \\
\text { BCR4.4: Actors shall be aware of the adopted strategy } \\
\text { BCR4.5:The reusable components in the company shall be identified }\end{array}$ \\
\hline
\end{tabular}

As it can be observed based on the requirements in Table 7, the purpose of this area is to ensure that main aspects of the concerned business models such as business goals, visions and strategies are defined documented and shared. It also ensures that business models are designed for collaboration with multiple partners and that are adaptive regarding its environment (Solaimani and Bouwman, 2012), (Guédria et al., 2015). MMEI enumerates the following components of a business model that are relevant to the interoperability assessment: information about strategy, politic, rules, hierarchy, objective, functions, services, processes and partners of the enterprise. Hence, to ensure business interoperability, these components should be defined.

Moreover, the business model can be only understood by the person defining it i.e. the meaning of the business model is in the mind of the person who defines it, which leads to work on the tacit knowledge (Lezoche et al., 2012), (Guédria et al., 2015). To 
make information accessible, a business model should be documented and shared among the concerned stakeholders. A business model can be documented in many forms e.g. an electronic version in PDF, a printed document, etc. For ensuring semantic interoperability, one has to maximise the amount of explicit semantics in the represented models (Obrst, 2003). In addition, standards can be used in order to facilitate the semantic and syntactic alignment with other models in case of interoperations with multiple partners.

For ensuring and sustaining business interoperability, business models should be designed considering the enterprise environment and the potential internal and external collaborations. For that reason, existing and potential interactions with partners should be highlighted and explicitly defined in the considered business model for ensuring the business alignment (Solaimani et al., 2015). Considerations from all stakeholders shall be integrated a priori engaging collaborations.

Nevertheless, when collaborations are already happening, and new partners are involved, such business models should adapt. An adaptive business model means that it can be modified without negatively affecting the business performance (Chesbrough, 2007), (Ricciardi et al., 2016). These modifications should be based on informed decisions (Proper, 2014). Therefore, periodic review procedures for monitoring the performance and evolution of business should be defined and in place. Such reviews allow to identify any difficulties and changes "on the fly", despite being internal to the enterprise or regarding the interactions between partners (Guédria et al., 2015).

Figure 7 illustrates the instantiation of some IRs and their relations to enterprise elements, based on the defined conceptual model in Figure 6. 


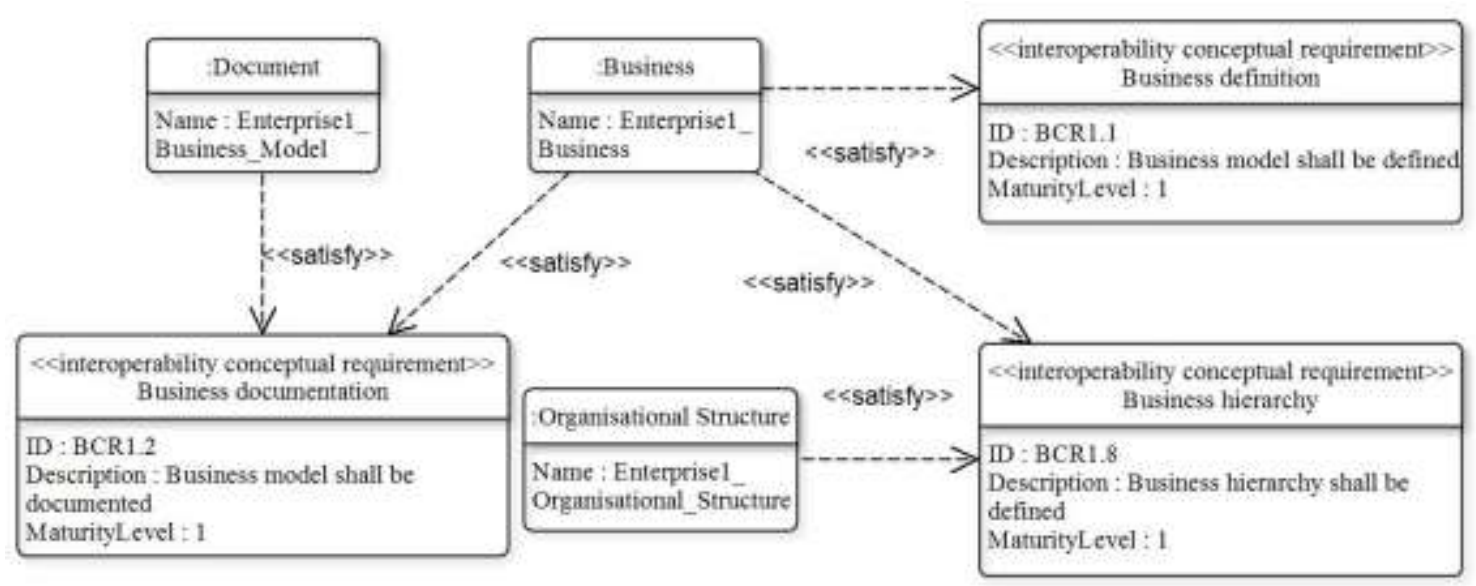

Figure 7. Requirements from the Business-Conceptual interoperability area

In Figure 7, three instances of IRs are illustrated. These instances are BCR1.1: Business model shall be defined, BCR1.2: Business model shall be documented and BCR1.8: Business hierarchy shall be defined. These instances have also their attributes depicted. These attributes correspond to the requirement $I D$, the requirement Description and the associated Maturity Level. It can be also observed that each one of these requirements are related to an Enterprise Element trough an association related to. The generalisation of the class Enterprise Element that are considered are: Business, Document and Organisational Structure. For clarity sake, the authors do not illustrate the element Enterprise1, which is an instantiation of the class Enterprise. Nevertheless, note that Enterprise1_Business, Enterprise1_Business_Model and Enterprise1_Organisational_Structure are elements that aggregates Enterprise1.

Further, the requirement BCR1.1 is related to the Enterprise1_Business, which is an instance of the class Business. The requirement BCRl.8 is related to the Enterprise1_Business and to the Enterprise1_Organisational_Structure. Indeed, the organisational structure definition (or at least the main roles) is an important part of a business. Finally, the requirement BCR1.2 is relate to the Enterprise1_Business and to a document called Enterprise1_Business_Model. 


\subsection{Interoperability Requirements Interdependencies Determination}

Having the requirements decomposed and allocated to enterprise elements, the same or similar atomic requirements that are used by different requirements and addressed to the same enterprise elements can be identified. Based on these relationships, the IRs interdependencies are defined. In addition, the formalised form of the requirements are also considered, especially those requirement that contains the $U$ temporal connector (Emerson and Halpern, 1986). As an example, hereinafter the interdependences focusing on the Business Interoperability Concern are defined.

When considering the collaborative context, business models should be defined accordingly to the collaboration goals and semantic alignment across the network for avoiding misinterpretation (See IR $B C R 3$ ). In addition, changes on business models can lead to changes on different enterprise elements, in a single enterprise or on multiple network partners.

An illustrative example could be a networked enterprise composed of three bookstores that want to improve their book delivery delays in order to increase their sales and client satisfaction. To do so, the enterprise responsible for the delivery decides to implement a new customer data processing system, focusing on the customer location information. It would imply the change of existing information systems and their interfaces, leading to the questions: Can the existing databases communicate with the new processing system? Can the information systems already in place in the other stores exchange information with the new system? Can employees learn in an easy and smooth way to operate the new system? Moreover, what will be the changes to the overall book delivery process? Hence, it can be can observed that such models have relations with the process and service concerns as they should be aligned with the business goals that are stated on the concerned business model. 
When considering the agility and dynamicity of such model, i.e. how fast changes can be made and how flexible they are, various enterprise elements should be taken into account. For example, stakeholders desire to improve their performance in their market by seizing a collaboration opportunity. However, for capturing and running such opportunities, enterprises should verify if their business supports collaboration as well as if their structures (be organisational or technological) are open to changes. In other words, in order to fulfil the requirements BCR3: Business Models shall be designed for collaboration and BCR4: Business models shall be adaptive, requirement from the Business-Organisational and Business-Technological interoperability areas should be considered.

Some of the identified interdependencies are depicted in Figure 8. To represent the dependencies between the requirements, the "Usage" dependency is used. It is defined in the UML as: A Usage is a dependency in which one NamedElement requires another NamedElement (or set of NamedElements) for its full implementation or operation (OMG, 2017b). A NamedElement can be any class that has a name such as the Interoperability Requirement class (see Figure 6). For the purpose of this paper, the term "requires" is used as an instance of the "Usage" dependency. In addition, the "requirement" dependencies are coloured in red for improving visibility.

In Figure 8, it can be observed that BCR1.8: Business hierarchy shall be defined and BOR 1: Organisational structure shall be defined and put in place are both related to the same Enterprise Element, which is the concerned Organisational Structure. From this relationship, it can be inferred that these requirements are interdependent as both states that the organisational structure should be defined. The dependencies between these two requirements, shows that there are indeed at least one interdependency between BusinessConceptual and Business-Organisational interoperability areas. 
Further, the authors argue that the requirement $B C R l .1$ shall be satisfied before deploying relevant hardware for supporting business (BT1.3). Thus, there is a dependency between BTR1.3 and BCR1.1, which represents a relationship between the BusinessConceptual and Business-Technological areas.

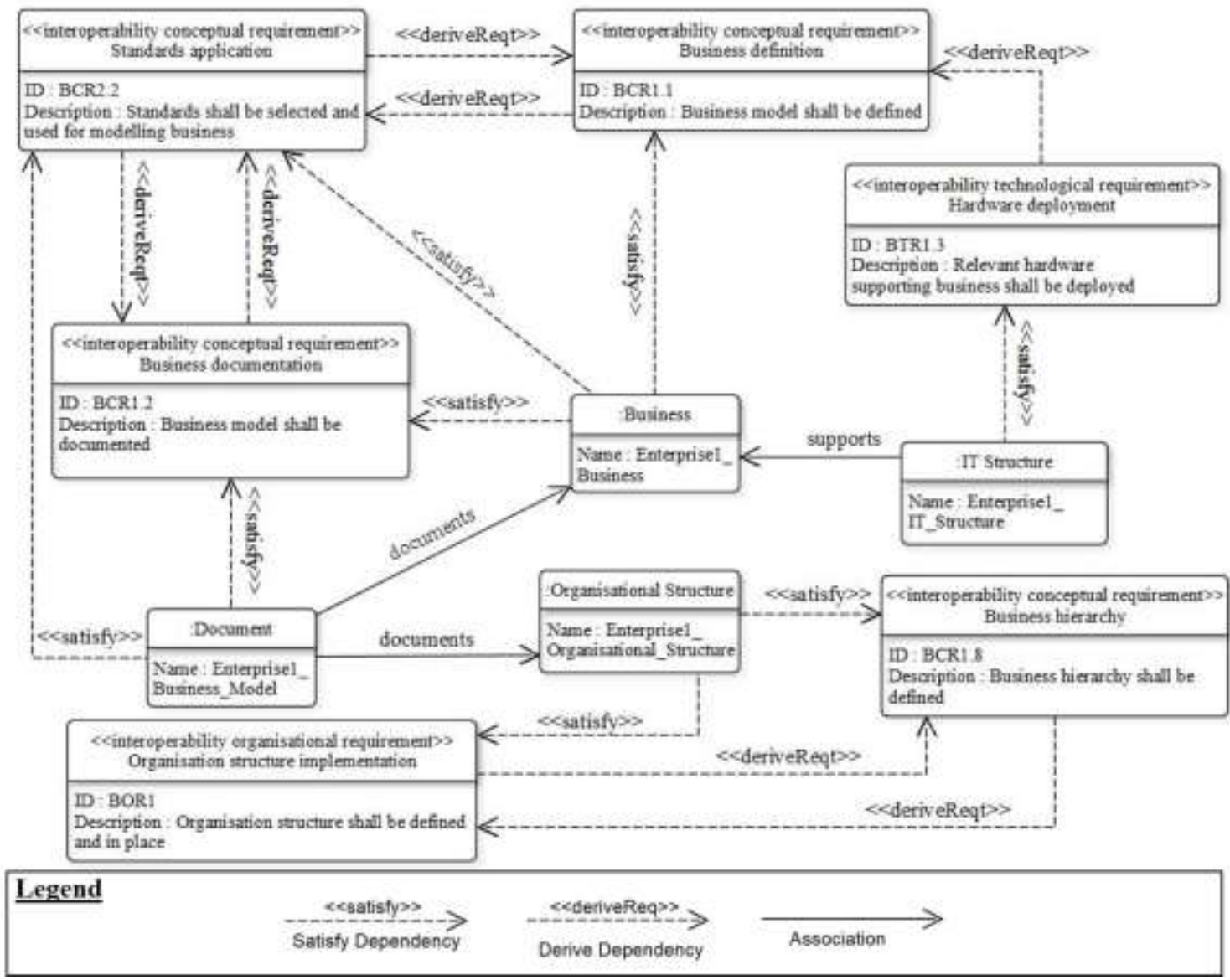

Figure 8. The IRs interdependences using the SysML notation (OMG, 2017a)

Finally, an interdependency among the requirements BCR1.1, BCRl.2 and $B C R 2.2$ is identified. Indeed, when the $B C R 2.2$ requirement should be considered while defining and documenting a business model. Nevertheless, a business model can still be defined and documented without a standard, but the potential to interoperability problems to occur is higher. Note that not all interdependencies regarding the illustrated IRs are depicted. For example, the dependency between BCR1.2: Business models shall be 
documented towards BCR1.1: Business models shall be defined is not explicitly illustrated.

Figure 9 and Figure 10 illustrate the requirements interdependencies based on requirements decomposition and formalisation.

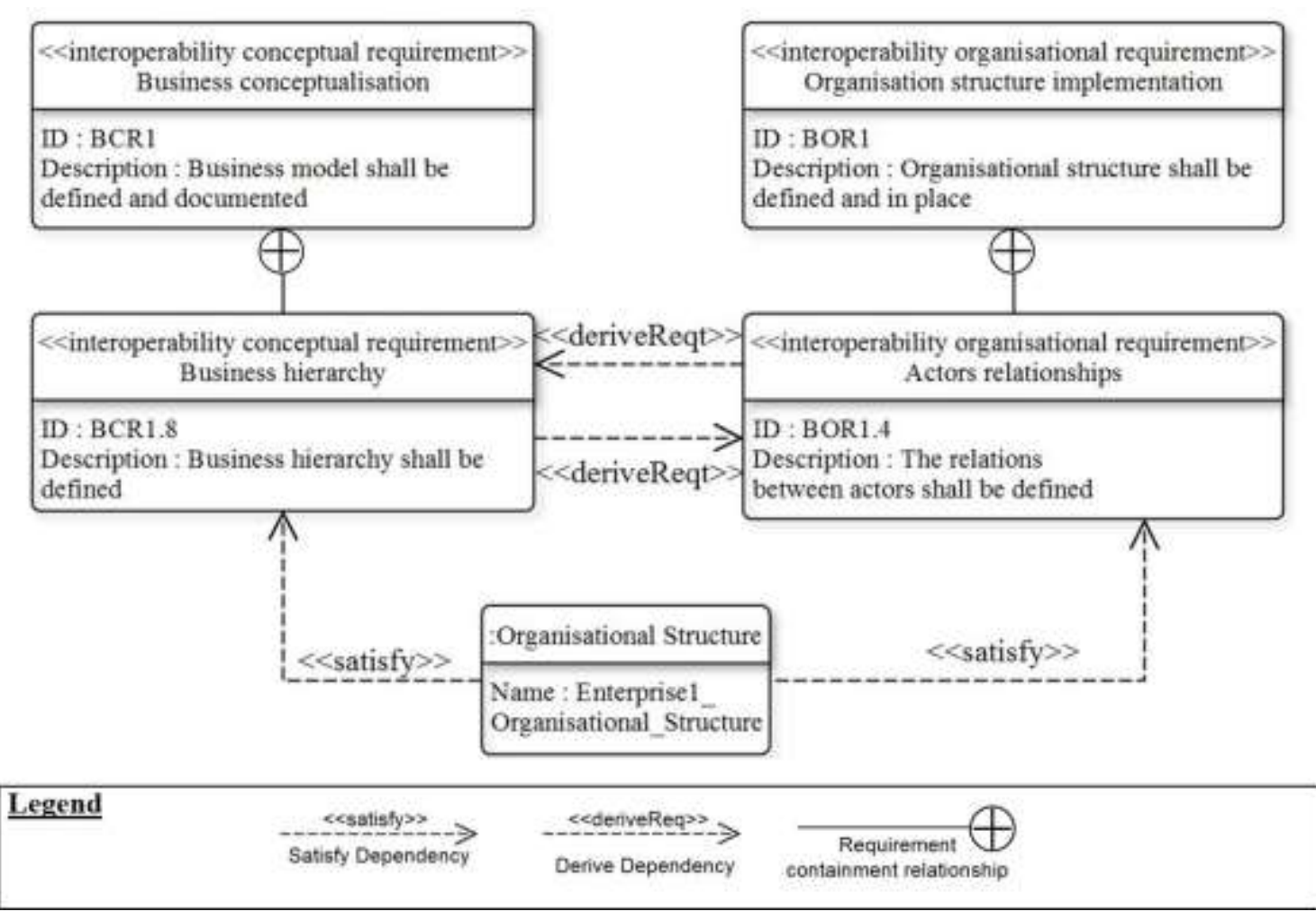

Figure 9. The IRs interdependences based on the atomic requirements using the SysML notation (OMG, 2017a)

In Figure 9, it can be observed that the atomic requirements BCR1.8: Business hierarchy shall be defined and the BOR1.4: The relations between actors shall be defined are related to the same enterprise element, which is the Enterprise1_Organisational_Structure. Based on their descriptions, the authors argue that they are similar to each other. Therefore, both atomic requirements are interdependent. This interdependency can be written as an AND $\left({ }^{\wedge}\right)$ when writing using the first order logic. 


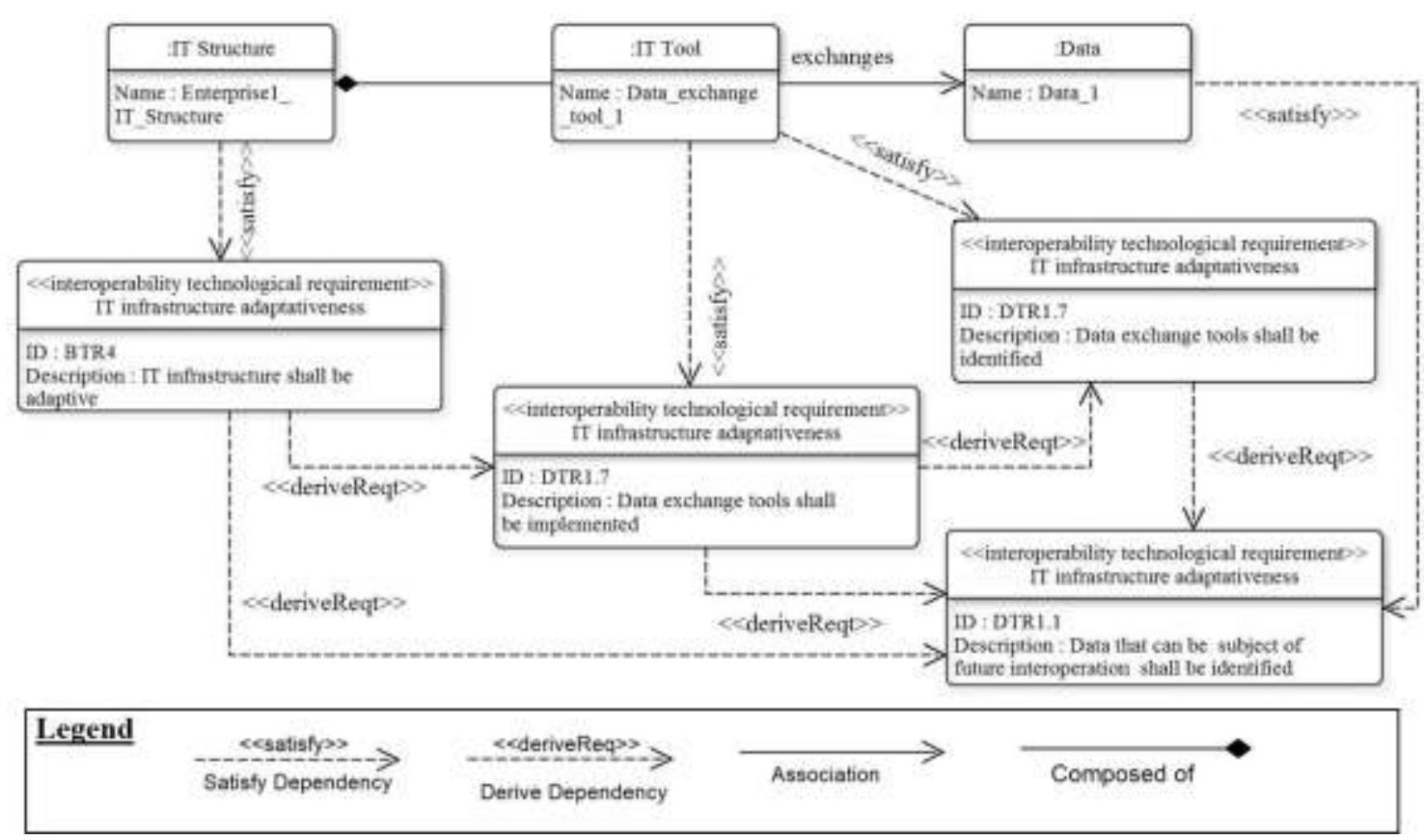

Figure 10. The IRs interdependences based on the U logical connector using SysML notation (OMG, 2017a)

In Figure 10, it can be observed that the requirement BTR4: IT infrastructure shall be adaptive requires that the atomic requirement DTR1.7: Data exchange tools shall be implemented is fulfilled. Considering the temporal dependencies (defined with the $\mathrm{U}$ connector) from the atomic requirement DTR1.7, the authors argue that BTR4 also requires the atomic requirement DTR1.1: Data that can be subject of future interoperation shall be identified.

As an example, Table 8 presents the IRs from the Business Conceptual Interoperability area from the maturity level 1 . This table presents the decomposition the concerned IR, the requirements that are required by the concerned IR and the requirements that require the concerned IR. 
Table 8. Requirement BCR1

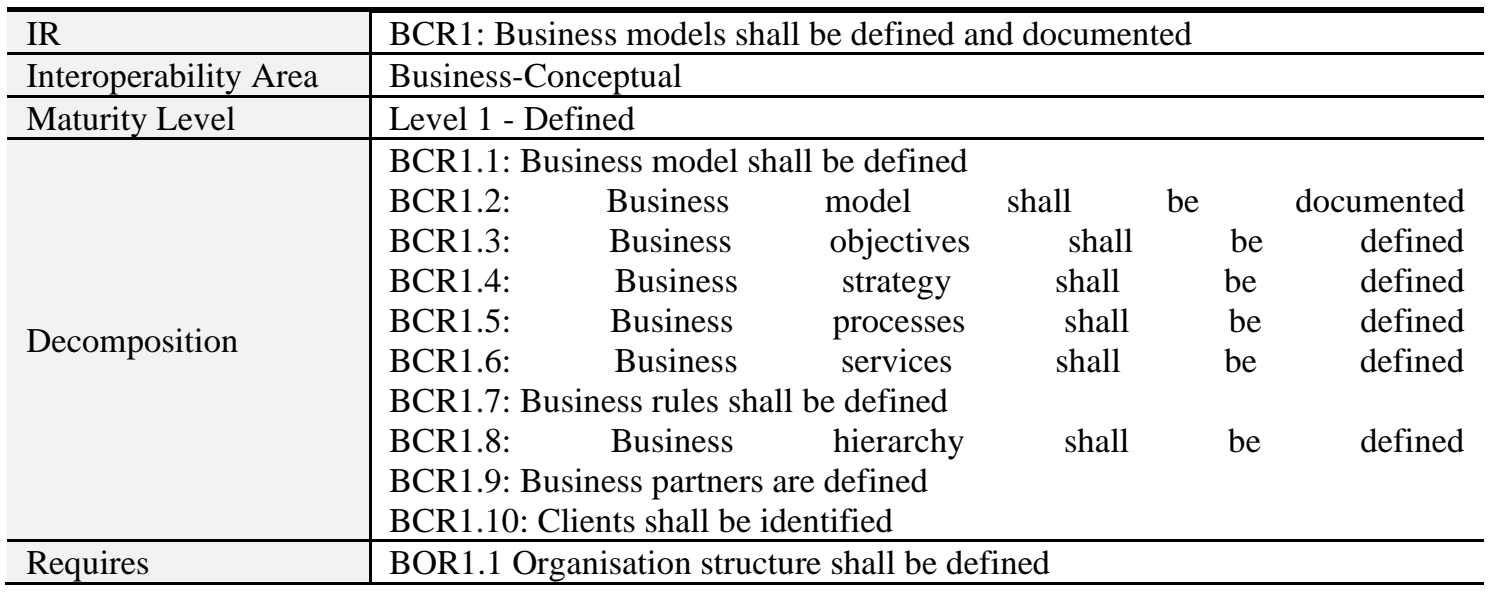

A list containing all the 48 IR and their interdependencies can be found in the Annexe A in (Leal 2019).

\section{Evaluation}

In this section, a use case is used to demonstrate and evaluate the proposed contribution. The case concerns a multinational company specialized in automobile manufacturers including wiring harness systems, exclusive interiors and electrical components. For confidentiality reasons, the name of the enterprise is omitted. "CarPartsCo" is used to refer to the company. The company is a subsidiary of a German automotive component supplier. CarPartsCo intends to become more agile and flexible for improving their response to new business opportunities and collaborations. To ensure its functions and reach its objectives, the company needs to interoperate with many partners, including its headquarters in Germany. However, some challenges regarding interoperation between CarPartsCo and its business partners are impeding their effective collaboration. Thus, the proposed contribution is applied for identifying the existing and potential interoperability barriers that may impact the overall systems. Two phases were used to conduct the assessments in order to come to valuable results and optimal feedbacks. 
The first one was the preparation phase in which interviews and workshops were conducted with key employees of the CarPartsCo. It was done in order to gather relevant data concerning their mode of functioning, their collaborative tasks and perceived problems and risks. Further, in this phase, an analysis of the collected data allowed us to design the as-is situation (main processes, resources, ICT infrastructure, etc.). The second one was the he assessment phase in which two assessors evaluated the enterprise interoperability. The assessment was done by applying the MMEI to determine the maturity of the enterprise, to highlight their ability to be interoperable with their environment and pointing out potential problems that may influence the interoperation.

\subsection{Preparation phase}

The data collection was done based on interviews with their key employees. Two workshops concerning the CarPartsCo structure and services were also organised. Documents sent by CarPartsCo were also used to complement our analysis. The questionnaire used for the interviews was semi-structured, and the questions were used to initiate discussion on identified issues. Based on the collected data, the CarPartsCo asis situation was analysed, which the result is briefly described next.

The company has 10 departments, including the General Direction, Production Management and Human Resources Department. The main stakeholders are the headquarters in Germany, a production site in Poland, suppliers all around Europe and customs for export. In the next section, we present the interoperability assessment of CarPartsCo based on the interviews and provided documents.

\subsection{Assessment phase}

During the assessment phase, the 48 criteria from the twelve areas of interoperability were considered. Based on the gathered information the maturity level is determined and best 
practices are proposed. Table 9 depicts the summary of the CarPartsCo assessment considering each interoperability area: Business-Conceptual (BC), BusinessTechnological (BT), Business-Organisational (BO), Process-Conceptual (PC), ProcessTechnological (PT), Process-Organisational (PO), Service-Conceptual (SC), ServiceTechnological (ST), Service-Organisational (SO), Data-Conceptual (DC), DataTechnological (DT) and Data-Organisational (DO).The linguistic variables used for rating the criteria are the same as established on the current version of MMEI: "Not Achieved (NA)", "Partially Achieved (PA)", "Largely Achieved (LA)" and "Fully Achieved (FA)".

Table 9. The evaluation criteria rating

\begin{tabular}{|c|c|c|c|c|c|c|c|c|c|c|c|}
\hline Area & ID & Rate & Area & ID & Rate & Area & ID & Rate & Area & ID & Rate \\
\hline \multirow{4}{*}{$B C$} & BCR1 & FA & \multirow{4}{*}{$P C$} & PCR1 & FA & \multirow{4}{*}{$S C$} & SCR1 & $\overline{F A}$ & \multirow{4}{*}{$D C$} & DCR1 & $\overline{F A}$ \\
\hline & BCR2 & LA & & PCR2 & LA & & SCR2 & LA & & DCR2 & FA \\
\hline & BCR3 & LA & & PCR3 & NA & & SCR3 & NA & & DCR3 & NA \\
\hline & BCR4 & LA & & PCR4 & PA & & SCR4 & LA & & DCR4 & NA \\
\hline \multirow{4}{*}{$B T$} & BTR1 & FA & \multirow{4}{*}{$P T$} & PTR1 & FA & \multirow{4}{*}{$S T$} & STR1 & FA & \multirow{4}{*}{$D T$} & DTR1 & FA \\
\hline & BTR2 & FA & & PTR2 & LA & & STR2 & LA & & DTR2 & LA \\
\hline & BTR3 & LA & & PTR3 & LA & & STR3 & LA & & DTR3 & LA \\
\hline & BTR4 & PA & & PTR4 & LA & & STR4 & PA & & DTR4 & NA \\
\hline \multirow{4}{*}{$B O$} & BOR1 & FA & \multirow{4}{*}{$P O$} & POR1 & FA & \multirow{4}{*}{ SO } & SOR1 & FA & \multirow{4}{*}{$D O$} & DOR1 & FA \\
\hline & BOR2 & FA & & POR2 & LA & & SOR2 & LA & & DOR2 & LA \\
\hline & BOR3 & LA & & POR3 & LA & & SOR3 & LA & & DOR3 & NA \\
\hline & BOR4 & LA & & POR4 & LA & & SOR4 & NA & & DOR4 & NA \\
\hline
\end{tabular}

Considering the MMEI measurement mechanism (Guédria et al., 2015), CarPartsCo obtained a maturity equal to "Level 2 - Aligned". This level is characterised by the following statement: An aligned enterprise is able to make changes in its components in order to adhere to common references. Processes, models, data and services are managed and mostly based on standards or common formats and practices. It is possible to adjust models, services or business policies, in order to adapt to environmental changes. In case of interoperation, the concerned sub-system provides adequate resources and assigns responsibility for performing this interoperation. 
Interoperability training has been performed for key personnel. Some guidelines exist to describe how interoperability can occur and how to adjust the business if needed. Reaching this level of interoperability maturity allows an enterprise to have a stable environment in which long term and stable partnerships can be established with its known suppliers, sub-contractors and customers.

It is important to note that a lower interoperability maturity for a company does not systematically mean a dysfunction at all levels and for all functions of the company. The maturity is only evaluated from the interoperability point of view and cannot be applied for another purpose (e.g. product quality or financial performance). Table 10 summarises the interoperability barriers encountered.

Table 10. Interoperability barriers from the CarPartsCo

\begin{tabular}{l|l|l}
\hline Concern & Barrier & Description \\
\hline $\begin{array}{l}\text { Service, } \\
\text { Process, } \\
\text { Business }\end{array}$ & $\begin{array}{l}\text { Semantics and Syntax } \\
\text { incompatibilities }\end{array}$ & $\begin{array}{l}\text { Even though the company using an internal standard and sharing with } \\
\text { its suppliers, no meta-model is defined for allowing the extensions of } \\
\text { the supplier networks. } \\
\text { Some process models can be used and adapted to develop other } \\
\text { processes but this is not done rapidly }\end{array}$ \\
\hline Data & $\begin{array}{l}\text { Lack of guidelines for } \\
\text { personalized data } \\
\text { management }\end{array}$ & $\begin{array}{l}\text { No rules or methods for data personalization for interacting with } \\
\text { different partners }\end{array}$ \\
\hline Service & $\begin{array}{l}\text { Interface } \\
\text { incompatibilities }\end{array}$ & $\begin{array}{l}\text { Applications are only shared with headquarters. However, when } \\
\text { sharing applications and services with partners, the interoperation are } \\
\text { done ad-hoc. }\end{array}$ \\
\hline Business & $\begin{array}{l}\text { IT } \\
\text { incompatibilities }\end{array}$ & $\begin{array}{l}\text { Reusable components for processes and services and some home- } \\
\text { made applications exist. However, the home-made applications } \\
\text { cannot exchange information with the main information flow of the } \\
\text { network of partners. }\end{array}$ \\
\hline
\end{tabular}

Figure 11 illustrates the IRs related to the CarPartsCo components and the identified potential problems. Note that the problems are illustrated as "lightening". 

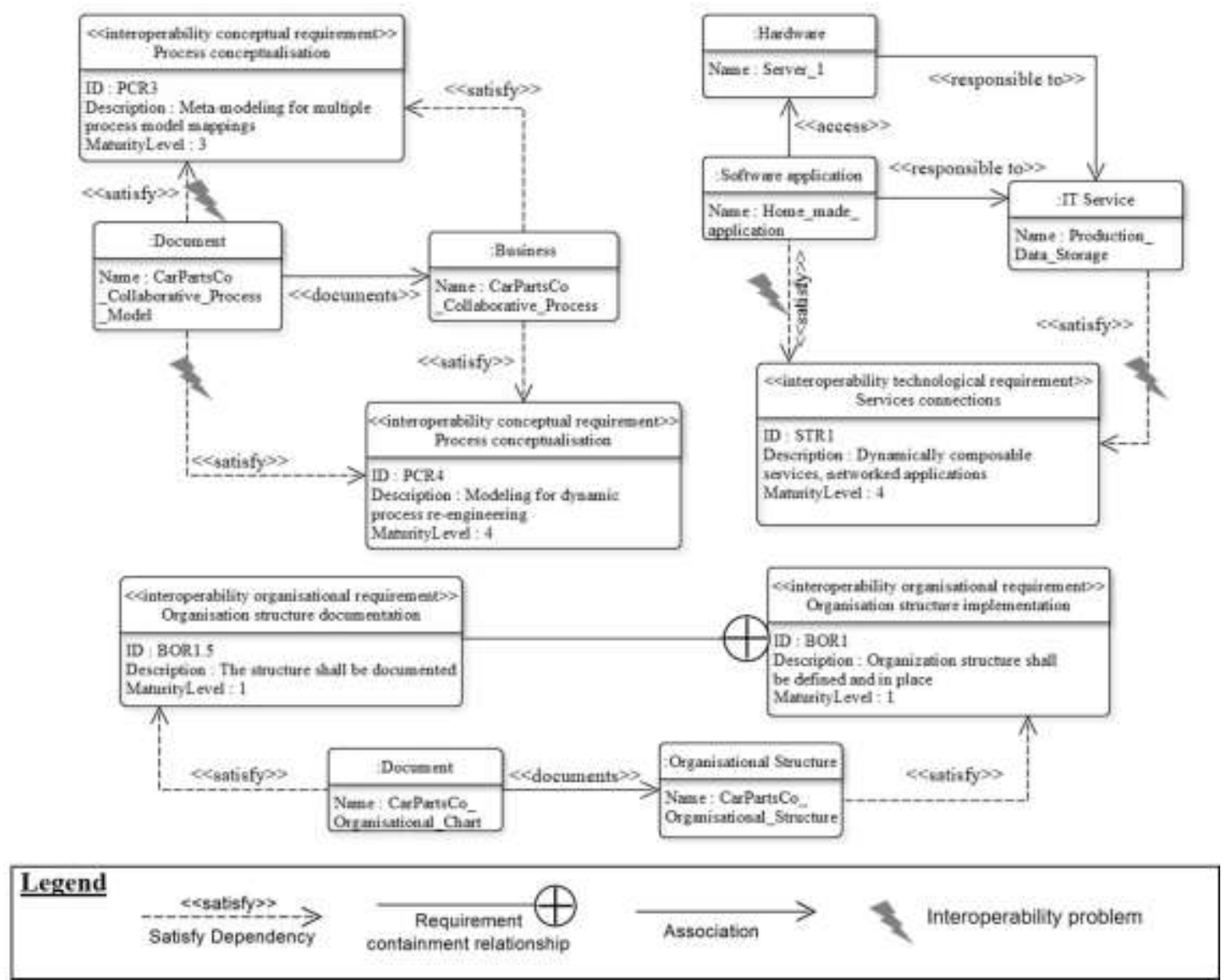

Figure 11. Some of the barriers identified in the INNOV case

Indeed, as illustrated in Figure 11, a potential barrier to interoperability can occur, as the CarPartsCo_Collaborative_Process_Model is not modelled in a way that favours collaboration with new external partners. It has also a weakness regarding its adaptability. Note that it does not means that the CarPartsCo_Collaborative_Process is underperforming, but that misalignment with potential partners can happen within a collaboration as process information are not planned.

Finally, a potential technological barrier regarding the storage of production data was also identified. It is due the fact that the management of production information flow (i.e. the service Production_Data_Storage) is difficult. Indeed, CarPartsCo employees should enter and monitor the production information in the Home_made_application. However, to share with its partners, the concerned employees should copy and paste the 
information in an standardized software used by the network. The latter can cause disturbances and misalignment in the defined information flow. It can be also difficult to ensure information robustness within the enterprise and partners if information is dispersed in different databases.

Based on these results, a list of best practices was provided for removing or at least reducing the negative impacts of the identified interoperability barriers. Table 11 and Table 12 describe, as an example, the best practices related to the Process-Conceptual and Service-Technical areas.

Table 11. Best practices related to the PCR3 requirement

\begin{tabular}{l|l}
\hline Requirement & PCR3: Meta-Models for multiple process mapping shall be defined \\
\hline $\begin{array}{l}\text { Requirement that } \\
\text { are being }\end{array}$ & PCR4: Process modelling supports dynamic re-engineering \\
influenced & PTR3: Platforms and tools for collaborative processes shall be in place \\
\hline Best Practices & BPPC3.1. Define meta models for existing process models \\
(specific for & BPPC3.2. Identify concepts that are used by the main partners (past or future ones) \\
PCR3) & BPPC3.3. Use meta models for the process models definition \\
\hline
\end{tabular}

Table 12. Best practices related to the STR4 requirement

\begin{tabular}{|c|c|}
\hline Requirement & STR4: Dynamically composable services, networked applications \\
\hline $\begin{array}{l}\text { Requirement that } \\
\text { are being } \\
\text { influenced }\end{array}$ & $\begin{array}{l}\text { PTR3: Platforms and tools for collaborative processes shall be in place } \\
\text { PTR4: IT tools shall be dynamic and adaptive } \\
\text { DTR4: Direct database exchanges capability and full data conversion tool. }\end{array}$ \\
\hline $\begin{array}{lr}\text { Best } & \text { Practices } \\
(\text { specific } & \text { for } \\
\text { PCR3) } & \end{array}$ & $\begin{array}{l}\text { BPST4.1. Identify tools and platforms that support dynamic services engineering } \\
\text { BPST4.2. Decompose services into manageable and composable elements }\end{array}$ \\
\hline
\end{tabular}

\section{Conclusion}

Among the challenges faced by enterprises, the development, management and improvement of interoperability have come once again under the spotlight. In this context, INnteroperability ASsessment (INAS) is paramount for analysing the current state of enterprises and their systems and for supporting the interoperability development. However, there are some limitations to the current INAS approaches. For instance, these approaches are not explicitly defining Interoperability Requirements (IRs) interdependencies. To cover the identified limitation, a Requirements Engineering 
approach is adopted for identifying, formalising requirements and for defining their interdependencies.

The Maturity Model for Enterprise Interoperability (MMEI) was used as the reference model for extracting interoperability evaluation criteria. Such a model provides insights and criteria considering multiple interoperability layers and enterprise levels. Further, the evaluation criteria from MMEI were re-written as IRs using the guidelines proposed in the ISO 29148. Then, the defined 48 IRs were decomposed and formalised. This allowed identifying the IRs that have the same or similar atomic requirements, as well as those requirements that are addressing the same enterprise system. The IRs interdependencies were defined based on the atomic requirements similarities and the relations between enterprise systems and multiple IRs. To demonstrate and evaluate the proposed contribution, an assessment in a real company from the manufacturing sector was conducted.

The current version of MMEI provides a list of best practices for avoiding potential interoperability problems and removing existing ones. However, the selection of the recommended practices depends on the objectives of the enterprise and the expertise of decision makers. As future work, the authors intend to improve MMEI with multi-criteria techniques for supporting the interoperability solutions prioritization, taking into account the different influences and impacts on the overall system. Another perspective is to include the defined IRs interdependencies on the computer-mediated interoperability assessment system proposed in (Leal et al., 2019b). Such system will help support assessment process by allowing, in an automated manner, the determination of the quality of interoperability and identification of non-compliant requirements and their negative influences. 


\section{Acknowledgements}

This work has been conducted in the context of the PLATINE project (PLAnning Transformation Interoperability in Networked Enterprises), financed by the national fund of research of the Grand Duchy of Luxembourg (FNR), under the grant C14/IS/8329172/R2.

\section{References}

Agostinho, C., Ducq, Y., Zacharewicz, G., Sarraipa, J., Lampathaki, F., Poler, R., Jardim-Goncalves, R., 2016. Towards a sustainable interoperability in networked enterprise information systems: Trends of knowledge and model-driven technology. Computers in Industry 79, 64-76. https://doi.org/https://doi.org/10.1016/j.compind.2015.07.001

Ahn, J., Lee, J.S., Kim, H.J., Hwang, D.J., 2016. Smart city interoperability framework based on city infrastructure model and service prioritization, in: 2016 Eighth International Conference on Ubiquitous and Future Networks (ICUFN). IEEE, Vienna, Austria, pp. 337-342. https://doi.org/10.1109/ICUFN.2016.7537044

Alemany, M.M.E., Alarcón, F., Lario, F.C., Poler, R., 2010. Conceptual Framework for the Interoperability Requirements of Collaborative Planning Process, in: Popplewell, K., Harding, J., Poler, R., Chalmeta, R. (Eds.), Enterprise Interoperability IV: Making the Internet of the Future for the Future of Enterprise. Proceedings of I-ESA 2010. Springer London, Coventry, UK, pp. 25-34. https://doi.org/10.1007/978-1-84996-257-5_3

Amyot, D., Ghanavati, S., Horkoff, J., Mussbacher, G., Peyton, L., Yu, E., 2010. Evaluating goal models within the goal-oriented requirement language. International Journal of Intelligent Systems 25, 841877. https://doi.org/10.1002/int.20433

Backman, J., Väre, J., Främling, K., Madhikermi, M., Nykänen, O., 2016. IoT-based interoperability framework for asset and fleet management, in: 2016 IEEE 21st International Conference on Emerging Technologies and Factory Automation (ETFA). IEEE, Berlin, Germany, pp. 1-4. https://doi.org/10.1109/ETFA.2016.7733680

Berre, A.-J., Elvesaeter, B., Figay, N., Guglielmina, C., Johnsen, S.G., Karlsen, D., Knothe, T., Lippe, S., 2007. The ATHENA Interoperability Framework, in: Goncalves, RJ and Muller, JP and Mertins, K and Zelm, M. (Ed.), Enterprise Interoperability II: New Challenges and Approaches. pp. 569-580. https://doi.org/10.1007/978-1-84628-858-6_62

Camarinha-Matos, L.M., Afsarmanesh, H., 2005. Collaborative networks: a new scientific discipline. Journal of Intelligent Manufacturing 16, 439-452. https://doi.org/10.1007/s10845-005-1656-3

Cestari, J.M.A.P., Loures, E. de F.R., Santos, E.A.P., Panetto, H., 2019. A capability model for public administration interoperability. Enterprise Information Systems 1-31. https://doi.org/10.1080/17517575.2018.1564154

Chen, D., Dassisti, M., Elvesaeter, B., Panetto, H., Daclin, N., Jaekel, F.-W., Knothe, T., Solberg, A., 
Anaya, V., Gisbert, R.S., Kalampoukas, K., Pantelopoulos, S., Kalaboukas, K., Bertoni, M., Bor, M., Assogna, P., 2007. DI.3: Enterprise Interoperability-Framework and knowledge corpus-Advanced report Deliverable DI.3, INTEROP NoE (Network of Excellence on Interoperability research for Networked Enterprise).

Chesbrough, H., 2007. Business model innovation: it's not just about technology anymore. Strategy \& Leadership 35, 12-17. https://doi.org/10.1108/10878570710833714

Chituc, C.-M., Azevedo, A., Toscano, C., 2009. A framework proposal for seamless interoperability in a collaborative networked environment. Computers in Industry 60, 317-338. https://doi.org/10.1016/j.compind.2009.01.009

Cornu, C., Chapurlat, V., Quiot, J.-M., Irigoin, F., 2012. Customizable Interoperability Assessment Methodology to support technical processes deployment in large companies. Annual Reviews in Control 36, 300-308. https://doi.org/http://dx.doi.org/10.1016/j.arcontrol.2012.09.011

Daclin, N., Daclin, S.M., Chapurlat, V., Vallespir, B., 2016. Writing and verifying interoperability requirements: Application to collaborative processes. Computers in Industry 82, 1-18. https://doi.org/https://doi.org/10.1016/j.compind.2016.04.001

EIF, 2017. European Interoperability Framework - Implementation Strategy. Annex II of to the communication from the commission to the European parliament, the council, the European economic and social committee and the committee of the regions. Brussels.

Emerson, E.A., Halpern, J.Y., 1986. "Sometimes" and "not never" revisited: on branching versus linear time temporal logic. Journal of the ACM 33, 151-178. https://doi.org/10.1145/4904.4999

Eriksson, M., Börstler, J., Borg, K., 2009. Managing requirements specifications for product lines - An approach and industry case study. Journal of Systems and Software 82, 435-447. https://doi.org/10.1016/j.jss.2008.07.046

European Commission, 2018. Interoperability Maturity Assessment of a Public Service: IMAPS v1.1.1 User Guide.

European Commission, 2016. European agenda for the collaborative economy - supporting analysis, in the Communication from the Commission to the European Parliament, the Council, the European Economic and Social Committee and the Committee of the Regions. Brussels.

Ford, T.C., Colombi, J., Graham, S., Jacques, D., 2007a. The Interoperability Score, in: 5th Annual Conference on Systems Engineering Research (CSER). Hoboken, NJ, USA.

Ford, T.C., Colombi, J.M., Graham, S.R., Jacques, D.R., 2007b. A survey on interoperability measurement, in: International Command and Control Research and Technology Symposium (ICCRTS). Air Force Inst. of Tech. Wright-Patterson AFB OH, Rhode, Greece.

Gallaher, M.P., O’Connor, A.C., Dettbarn Jr., J.L., Gilday, L.T., 2004. Cost analysis of inadequate interoperability in the US capital facilities industry.

Gatti, R., Carbone, L., Mezzapesa, V., 2016. State of Play of Interoperability in Europe - The National 
Interoperability Framework observatory (NIFO) Report 2016. Luxembourg, Luxembourg. https://doi.org/10.2799/969314

Goepp, V., Avila, O., 2015. An Extended-Strategic Alignment Model for technical information system alignment. International Journal of Computer Integrated Manufacturing 28, 1275-1290. https://doi.org/10.1080/0951192X.2014.964774

Guédria, W., Naudet, Y., Chen, D., 2015. Maturity model for enterprise interoperability. Enterprise Information Systems 9, 1-28. https://doi.org/10.1080/17517575.2013.805246

Guédria, W., Naudet, Y., Chen, D., 2008. Interoperability Maturity Models -- Survey and Comparison --, in: Meersman, R., Tari, Z., Herrero, P. (Eds.), On the Move to Meaningful Internet Systems: OTM 2008 Workshops: OTM Confederated International Workshops and Posters, ADI, AWeSoMe, COMBEK, EI2N, IWSSA, MONET, OnToContent + QSI, ORM, PerSys, RDDS, SEMELS, and SWWS 2008, Monterrey, Mexico, November 9-14,. Springer Berlin Heidelberg, Berlin, Heidelberg, pp. 273-282. https://doi.org/10.1007/978-3-540-88875-8_48

IEEE, 1991. IEEE Standard Computer Dictionary: A Compilation of IEEE Standard Computer Glossaries, IEEE Std 610. https://doi.org/10.1109/IEEESTD.1991.106963

ISO/IEC 29148, 2011. ISO/IEC 29148: System and software engineering - Life cycle processes Requirements Engineering. ISO/IEC JTC 1/SC 7. Geneva.

ISO/IEC 33001, 2015. ISO/IEC 33001:2015 Information technology -- Process assessment -- Concepts and terminology. ISO/IEC JTC 1/SC 7.

ISO 11354-1, 2011. ISO 11354-1:2011 Advanced automation technologies and their applications -Requirements for establishing manufacturing enterprise process interoperability -- Part 1: Framework for enterprise interoperability. ISO/TC 184/SC 5.

ISO 11354-2, 2015. ISO 11354-2:2015 - Advanced automation technologies and their applications -Requirements for establishing manufacturing enterprise process interoperability -- Part 2: Maturity model for assessing enterprise interoperability. ISO/TC 184/SC 5.

ISO 15704, 2000. ISO 15704:2000 - Industrial automation systems -- Requirements for enterprise-reference architectures and methodologies. ISO/TC 184/SC 5. Geneva.

Jardim-Goncalves, R., Agostinho, C., Steiger-Garcao, A., 2012. A reference model for sustainable interoperability in networked enterprises: towards the foundation of EI science base. International Journal of Computer Integrated Manufacturing 25, 855-873. https://doi.org/10.1080/0951192X.2011.653831

Jochem, R., Knothe, T., 2007. Interoperability Requirements derived from Interoperability Dimensions, in: Gonçalves, R.J., Müller, J.P., Mertins, K., Zelm, M. (Eds.), Enterprise Interoperability II - New Challenges and Industrial Approaches, Proceedings of the 3th International Conference on Interoperability for Enterprise Software and Applications, IESA. Springer London, Funchal, Madeira Island, Portugal, pp. 39-50. https://doi.org/10.1007/978-1-84628-858-6_4 
Leal, G.S.S., 2019. Decision support for interoperability readiness in networked enterprises. Thesis Manuscript. Université de Lorraine, France.

Leal, G.S.S., Guédria, W., Panetto, H., 2019a. Interoperability assessment: A systematic literature review. Computers in Industry 106, 111-132. https://doi.org/10.1016/j.compind.2019.01.002

Leal, G.S.S., Guédria, W., Panetto, H., 2019b. A semi-automated system for interoperability assessment: an ontology-based approach, Enterprise Information Systems, https://doi.org/10.1080/17517575.2019.1678767

Leal, G.S.S., Guédria, W., Panetto, H., 2017. Assessing Interoperability Requirements in Networked Enterprises: A Model-Based System Engineering Approach. INSIGHT 20, 15-18. https://doi.org/10.1002/inst.12174

Lezoche, M., Yahia, E., Aubry, A., Panetto, H., Zdravković, M., 2012. Conceptualising and structuring semantics in cooperative enterprise information systems models. Computers in Industry 63, 775-787. https://doi.org/https://doi.org/10.1016/j.compind.2012.08.006

Loucopoulos, P., Karakostas, V., 1995. System Requirements Engineering, McGraw-Hil. ed. McGrawHill, New York, NY, USA.

Mallek, S., Daclin, N., Chapurlat, V., 2012. The application of interoperability requirement specification and verification to collaborative processes in industry. Computers in Industry 63, 643-658. https://doi.org/https://doi.org/10.1016/j.compind.2012.03.002

MEASURE Evaluation Team, 2017. Health Information Systems Interoperability Maturity Toolkit: Users' Guide.

Naudet, Y., Latour, T., Guedria, W., Chen, D., 2010. Towards a systemic formalisation of interoperability. Computers in Industry 61, 176-185. https://doi.org/http://dx.doi.org/10.1016/j.compind.2009.10.014

Neiva, F.W., David, J.M.N., Braga, R., Borges, M.R.S., Campos, F., 2016. SM2PIA: A Model to Support the Development of Pragmatic Interoperability Requirements, in: 2016 IEEE 11th International Conference on Global Software Engineering (ICGSE). pp. 119-128. https://doi.org/10.1109/ICGSE.2016.15

Nienhuys-Cheng, S.-H., Wolf, R., 1997. Foundations of Inductive Logic Programming, Lecture Notes in Computer Science. Springer Berlin Heidelberg, Berlin, Heidelberg. https://doi.org/10.1007/3-54062927-0

Obrst, L., 2003. Ontologies for semantically interoperable systems, in: Proceedings of the Twelfth International Conference on Information and Knowledge Management - CIKM '03. ACM Press, New York, New York, USA, p. 366. https://doi.org/10.1145/956863.956932

OMG, 2017a. OMG System Modeling Language (SysML), Version 1.5.

OMG, 2017b. Unified Modeling Language - Version: 2.5.1. Needham, USA.

Op't Land, M., Proper, E., Waage, M., Cloo, J., Steghuis, C., 2009. Enterprise Architecture: Creating Value by Informed Governance. Springer Berlin Heidelberg, Berlin, Heidelberg. 
https://doi.org/10.1007/978-3-540-85232-2

Panetto, H., 2007. Towards a classification framework for interoperability of enterprise applications. International Journal of Computer Integrated Manufacturing, Taylor \& Francis 20, 727-740. https://doi.org/10.1080/09511920600996419

Panetto, H., Berio, G., Benali, K., Boudjlida, N., Petit, M., 2004. A Unified Enterprise Modelling Language for Enhanced Interoperability of Enterprise Models. IFAC Proceedings Volumes 37, 605-610. https://doi.org/10.1016/S1474-6670(17)36181-5

Panetto, H., Zdravkovic, M., Jardim-Goncalves, R., Romero, D., Cecil, J., Mezgár, I., 2016. New perspectives for the future interoperable enterprise systems. Computers in Industry 79, 47-63. https://doi.org/http://dx.doi.org/10.1016/j.compind.2015.08.001

Peffers, K., Tuunanen, T., Rothenberger, M.A., Chatterjee, S., 2007. A Design Science Research Methodology for Information Systems Research. Journal of Management Information Systems 24, 45-77. https://doi.org/10.2753/MIS0742-1222240302

Peres, F., Yang, J., Ghazel, M., 2012. A Formal Framework for the Formalization of Informal Requirements. International Journal of Soft Computing and Software Engineering 2, 14-27. https://doi.org/10.7321/jscse.v2.n8.2

Proper, H.A., 2014. Enterprise Architecture: Informed Steering of Enterprises in Motion, in: Hammoudi, S., Cordeiro, J., Maciaszek, L., Filipe, J. (Eds.), Enterprise Information Systems. ICEIS 2013. Lecture Notes in Business Information Processing, Vol 190. Springer, Cham, Angers, France, pp. 16-34. https://doi.org/10.1007/978-3-319-09492-2_2

Rezaei, R., Chiew, T.K., Lee, S.P., Aliee, Z.S., 2014a. A semantic interoperability framework for software as a service systems in cloud computing environments. Expert Systems with Applications 41, 57515770. https://doi.org/https://doi.org/10.1016/j.eswa.2014.03.020

Rezaei, R., Chiew, T.K., Lee, S.P., Aliee, Z.S., 2014b. Interoperability evaluation models: A systematic review. Computers in Industry https://doi.org/https://doi.org/10.1016/j.compind.2013.09.001

Ricciardi, F., Zardini, A., Rossignoli, C., 2016. Organizational dynamism and adaptive business model innovation: The triple paradox configuration. Journal of Business Research 69, 5487-5493. https://doi.org/10.1016/j.jbusres.2016.04.154

Salinas, M.P.C., Prudhomme, G., Brissaud, D., 2008. Requirement-oriented activities in an engineering design process. International Journal of Computer Integrated Manufacturing 21, 127-138. https://doi.org/10.1080/09511920701607816

Selway, M., Stumptner, M., Mayer, W., Jordan, A., Grossmann, G., Schrefl, M., 2017. A conceptual framework for large-scale ecosystem interoperability and industrial product lifecycles. Data \& Knowledge Engineering 109, 85-111. https://doi.org/10.1016/j.datak.2017.03.006

Snydman, S., Sanderson, R., Cramer, T., 2015. The International Image Interoperability Framework (IIIF): 
A community \& technology approach for web-based images, in: IS\&T (Digital) Archiving Conference, Archiving 2015 Final Program and Proceedings, Color and Imaging Conference Final Program and Proceedings. Society for Imaging Science and Technology, Angeles, California, pp. 1621.

Solaimani, S., Bouwman, H., 2012. A framework for the alignment of business model and business processes. Business Process Management Journal 18, 655-679. https://doi.org/10.1108/14637151211253783

Solaimani, S., Bouwman, H., Itälä, T., 2015. Networked enterprise business model alignment: A case study on smart living. Information Systems Frontiers 17, 871-887. https://doi.org/10.1007/s10796-0139474-1

Ullberg, J., Chen, D., Johnson, P., 2009. Barriers to Enterprise Interoperability, in: Poler, R., van Sinderen, M., Sanchis, R. (Eds.), . Springer Berlin Heidelberg, pp. 13-24.

West Health Institute, 2013. The value of medical device interoperability. San Diego, California. 